\title{
Heavy Metals Presence in the Soil and Their Content in Selected Varieties of Chili Peppers in Slovakia
}

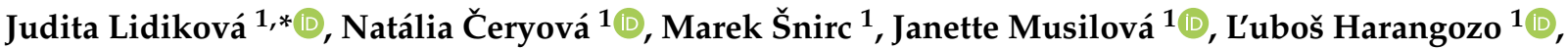 \\ Alena Vollmannová ${ }^{1}$, Jan Brindza ${ }^{2}$ and Olga Grygorieva ${ }^{3}$ (D)
}

1 Department of Chemistry, Faculty of Biotechnology and Food Sciences, Slovak University of Agriculture in Nitra, Tr. A. Hlinku 2, 94976 Nitra, Slovakia; xceryova@uniag.sk (N.Č.); marek.snirc@uniag.sk (M.Š.); janette.musilova@uniag.sk (J.M.); lubos.harangozo@uniag.sk (L'.H.); alena.vollmannova@uniag.sk (A.V.)

2 Department of Genetics and Plant Breeding, Faculty of Agrobiotechnology and Food Resources, Slovak University of Agriculture in Nitra, Tr. A. Hlinku 2, 94976 Nitra, Slovakia; jan.brindza@uniag.sk

3 Department of Fruit Plants Acclimatisation, National Botanical Garden of the National Academy of Sciences of Ukraine, Timiryazevska 1, 04014 Kyiv, Ukraine; olgrygorieva@gmail.com

* Correspondence: judita.lidikova@uniag.sk; Tel.: +421-37-641-4353

\section{check for} updates

Citation: Lidiková, J.; Čeryová, N.; Šnirc, M.; Musilová, J.; Harangozo, L'.; Vollmannová, A.; Brindza, J.; Grygorieva, O. Heavy Metals Presence in the Soil and Their Content in Selected Varieties of Chili Peppers in Slovakia. Foods 2021, 10, 1738. https://doi.org/10.3390/ foods10081738

Academic Editors: Antonello Santini and Natalia Arroyo-Manzanares

Received: 21 May 2021

Accepted: 26 July 2021

Published: 28 July 2021

Publisher's Note: MDPI stays neutral with regard to jurisdictional claims in published maps and institutional affiliations.

Copyright: (C) 2021 by the authors Licensee MDPI, Basel, Switzerland. This article is an open access article distributed under the terms and conditions of the Creative Commons Attribution (CC BY) license (https:// creativecommons.org/licenses/by/ $4.0 /)$

\begin{abstract}
Capsicum chili peppers are popular vegetables in Slovakia. They provide a supply of healthpromoting substances, but contaminated vegetables can pose a serious health risk to the people who consume them. Therefore, the aim of this study was to determine the content of heavy metals (Mn, $\mathrm{Zn}, \mathrm{Cr}, \mathrm{Cu}, \mathrm{Ni}, \mathrm{Cd}, \mathrm{Pb}$ and $\mathrm{Hg}$ ) in the soil as well as in selected varieties of the genus Capsicum grown in southern Slovakia. The results were compared with the limit values given by the Law no. 220/2004 (valid in the SR) as well as threshold values proposed by the European Commission (EC) (2006). The gained result showed that the total content of $\mathrm{Cd}(1.64 \mathrm{mg} / \mathrm{kg})$ as well as the available mobile forms of $\mathrm{Cd}(0.12 \mathrm{mg} / \mathrm{kg})$ and $\mathrm{Pb}(0.26 \mathrm{mg} / \mathrm{kg})$ was exceeded on the soil on which Capsicum cultivars were grown. The limit values of other monitored heavy metals $(\mathrm{Mn}, \mathrm{Zn}, \mathrm{Cr}, \mathrm{Cu}, \mathrm{Ni}$, and $\mathrm{Hg}$ ) were not exceeded. The studied species of the genus Capsicum did not accumulate monitored heavy metals. It can be stated that consumption of chili peppers does not pose any risk for human health.
\end{abstract}

Keywords: heavy metals; Capsicum; chili; food safety; cadmium

\section{Introduction}

Soil contamination with heavy metals has increased over the last few decades due to the burning of fossil fuels, municipal waste disposal, mining and smelting, as well as the application of pesticides, fertilizers and wastewater [1], including protected areas [2]. According to the FAO, heavy metals are non-biodegradable pollutants, characterized by high persistence in ecosystems and the ability to accumulate in the food chain $[3,4]$, whose already low concentrations can seriously damage the health of soils, plants, animals, and people [5,6]. For example, the Lowest Observed Adverse Effect Level (LOAEL) for Hg is $0.63 \mathrm{mg} / \mathrm{kg} /$ day, and the $\mathrm{Pb}$ blood level of $\geq 300 \mu \mathrm{g} / \mathrm{L}$ in children and adults is associated with slowing of nerve conduction velocity $[7,8]$. Heavy metals, such as $\mathrm{Cr}, \mathrm{Cd}, \mathrm{Hg}, \mathrm{Pb}$ and As, have been identified by the United States Environmental Protection Agency (USEPA) as a priority pollutant due to their persistence and irreversible toxic properties [9]. These metals can induce oxidative stress by generating free radicals and reducing antioxidant levels. The accumulation of heavy metals in the human body can lead to organ toxicity; they can especially have an effect on the gastrointestinal tract, and on the nervous, respiratory and reproductive systems $[10,11]$. Children may be particularly susceptible to heavy metal intoxication, which may adversely affect normal growth [12].

Lead $(\mathrm{Pb})$ and cadmium $(\mathrm{Cd})$ are common risk elements found in contaminated soil. $\mathrm{Pb}$ is one of the least mobile soil elements. Exposure to $\mathrm{Pb}$ may affect human health. Longterm exposure causes low IQ, and impaired neurobehavioral development and growth 
of children [13], cardiovascular problems, renal dysfunction, and may have genotoxic effects [14]. Cd is one of the most mobile and potentially bioavailable soil elements. It is used in many industrial processes such as the production of nickel-cadmium batteries, solar cells and electroplating [15]. It affects plant germination and growth, affects the rate of photosynthesis and reduces chlorophyll content $[16,17]$. In humans, $\mathrm{Cd}$ is reported to be carcinogenic [18]; epidemiological data point to $\mathrm{Cd}$ as a risk factor for lung, bladder and prostate cancer $[19,20]$. Cd induces cancer through several mechanisms, induces oxidative stress, inhibits apoptosis, damages DNA and inhibits DNA repair [21].

Unlike $\mathrm{Cd}$ and $\mathrm{Pb}$, some metals such as $\mathrm{Zn}, \mathrm{Mn}, \mathrm{Cu}$ and $\mathrm{Ni}$ belong to micronutrients, but at elevated concentrations their toxic effects may occur; e.g., $\mathrm{Cu}$ is required for enzymes such as tyrosinase and superoxide dismutase and plays an important role in the development of the central nervous system [22]. Zinc ( $\mathrm{Zn})$ is required for protein function and activity, for DNA synthesis as well as playing a role in male fertility [23], and in general it is one of the microelements (together with Se) very rare in food and plants. Some researchers suggested starting cultivation, in cooperation with farmers, of some wild species, e.g., Aegilops ventricosa Tausch that, unlike cultivated wheat varieties, has a higher quantity of microelements, such as $\mathrm{Zn}$, verifying the prospect of the production and marketing of its flour and/or pasta as a natural alternative to conventional medicine, and being helpful for people with $\mathrm{Zn}$ deficiencies [24,25]. $\mathrm{Zn}$ is an essential micronutrient, as it affects the activity and production of hundreds of different enzymes (dehydrogenases, peptidases, proteinases). It acts as a cofactor in enzymatic reactions involved in DNA expression, playing an important role in membrane stabilization and vitamin A metabolism [26]. High levels of $\mathrm{Zn}$ in the human body can disrupt the homeostasis of other essential elements. Large doses of $\mathrm{Zn}$ can interfere with lipoprotein metabolism. The long-term increased intake of $\mathrm{Zn}$ reduces the absorption of $\mathrm{Cu}$ and can cause its deficiency in the body. $\mathrm{Zn}$ has a relatively low toxicity and the serious effect of $\mathrm{Zn}$ intoxication on human health is a relatively rare phenomenon [27]. Acute $\mathrm{Zn}$ poisoning is manifested by vomiting, diarrhea and fever. For humans, $\mathrm{Zn}$ is not teratogenic or mutagenic.

Manganese (Mn) is a micronutrient needed in small amounts for human growth, development, and functioning, it is a cofactor of many enzymes (glutamine synthetase, arginase, pyruvate carboxylase) but in excessive amounts it can have strong neurotoxic effects. The neurotoxicity of $\mathrm{Mn}$ is associated with cognitive and motoric disorders, known as manganism. The exact underlying mechanism of Mn toxicity is unknown, but the clinical signs are identical to Parkinson's disease [28].

Chromium $(\mathrm{Cr})$ is a naturally occurring heavy metal that occurs in the environment as $\mathrm{Cr}^{3+}$ and $\mathrm{Cr}^{6+}$. $\mathrm{Cr}^{6+}$ can persist in soil or sediment for years, especially if the soils are sandy or contain low levels of organic matter [29]. Cr can be released into the air and drinking water from industrial processes. The reduction in $\mathrm{Cr}^{6+}$ to $\mathrm{Cr}^{3+}$ leads to the formation of reactive products that contribute to the cytotoxicity, genotoxicity and carcinogenicity of $\mathrm{Cr}^{6+}$-containing compounds [30]. Unlike $\mathrm{Cr}^{6+}, \mathrm{Cr}^{3+}$ is considered a micronutrient in humans, as it is essential for the metabolism of sugars and lipids. High doses of $\mathrm{Cr}$ and its long-term exposure can lead to various cytotoxic and genotoxic reactions that affect the body's immune system. Studies have shown that $\mathrm{Cr}^{6+}$ induces oxidative stress through the increased production of reactive oxygen species (ROS), leading to damage to genomic DNA and the oxidative degradation of lipids and proteins [31]. $\mathrm{Cr}^{6+}$ is an epithelial irritant, has genotoxic properties and is also considered a human carcinogen [32]. Copper (Cu) is an important cofactor in various cellular processes; it is essential for physiological processes such as Fe homeostasis [33], for the biosynthesis of neurotransmitters [34] and for energy metabolism, but increased content can cause various diseases in the human body. The absorption, uptake and transport of $\mathrm{Cu}$ are strictly regulated because too much and too little $\mathrm{Cu}$ is associated with oxidative cell damage, impaired immune function, and causes organ dysfunction. $\mathrm{Cu}$ imbalance is also associated with chronic liver disease, which comes from viral hepatitis infection or other liver damage. Cu toxicity can result in Wilson's disease. This rare disease is caused by a mutation in the gene and is characterized by 
excessive $\mathrm{Cu}$ accumulation [35]. Soluble $\mathrm{Cu}$ represents only a very small part of the total content of $\mathrm{Cu}$ in the soil. $\mathrm{Cu}$ has a high affinity for organic substances in the solid phase and therefore is not easily leached and can accumulate in surface soil.

Nickel is among the essential micronutrients utilized by plants, but high levels may be highly phytotoxic. Ni induces Fe and Zn deficiency and prevents the absorption of other heavy metals such as $\mathrm{Cd}, \mathrm{Cr}$ and $\mathrm{Pb}$ [36]. The major toxic effects of $\mathrm{Ni}$ on humans include allergic contact dermatitis for nickel, airway carcinogenicity, and reproductive toxicity [37].

$\mathrm{The}^{\mathrm{Hg}^{2+}}$ form of mercury plays a key role in the toxicology of this metal. High levels of this form have strong phytotoxic effects when present in toxic concentrations, they can cause visible injuries and physiological disorders in cells, which cause the production of ROS (reactive oxygen species), which in turn leads to cell disruption. $\mathrm{Hg}$ has a high affinity for biomolecules containing sulfhydryl (SH) groups [38]. The mechanism of $\mathrm{Hg}$ phytotoxicity may be through the displacement of metal ions from molecules (chlorophyll magnesium), the induction of changes in membrane and organelle permeability, and the inactivation of proteins [39]. High doses of $\mathrm{Hg}$ can have serious damaging effects on the developing nervous system, which can result in irritability, behavioral changes, tremors, headaches, hearing and cognitive impairment, dysarthria, and in changes to coordination. $\mathrm{Hg}$ is also toxic to the cardiovascular, immune, and reproductive systems. In the cardiovascular system, $\mathrm{Hg}$ causes hypertension in humans and animals, which has broad consequences, including changes in endothelial functions [38]. Inorganic $\mathrm{Hg}$ can cause kidney failure and damage to the gastrointestinal tract.

The transfer of heavy metals from contaminated soil to edible and consumed vegetables can compromise the quality of edible vegetables, food safety, and is a major route of human exposure to these metals [40].

Chili peppers (Capsicum annuum L., C. chinense L., C. baccatum L., C. frutescens L.) belong to the family Solanaceae and are grown in many parts of the world as important commercial crops (4.26 millions of tonnes produced worldwide in year 2019.) They are distinguished for their spicy and burning flavor due to presence of capsaicin. They originated in Mexico and other Central American areas, from where they spread throughout the world in the 17th century. Chili peppers are very popular, and are grown and consumed in Slovakia, especially in southern Slovakia. According to FAOSTAT, the production of chilies and peppers in Slovakia in 2019 was 4740 tonnes. These spicy varieties are characterized by high vitamin $C$ and polyphenol content, capsaicinoid content as well as high antioxidant activity, and are an integral part of traditional cooking [41,42]. Due to the high worldwide consumption of various species of the genus Capsicum as well as the use of capsaicin as a food additive and its current medical use, the monitoring and evaluation of toxic substances such as heavy metal accumulation in selected varieties of Capsicum is very important [43].

A study showed the genotoxic effect of $\mathrm{Cd}$ in pepper (C. annuum L.) as well as the excessive formation of superoxide radicals, which led to oxidative stress and increased lipid peroxidation in Capsicum tissues [44]. In another study, Pb showed a significant effect on cytomorphological traits in chili plants, and higher concentrations of $\mathrm{Pb}$ showed a genotoxic and mutagenic effect [45]. The consumption of vegetables as well as peppers of the genus Capsicum provide health benefits, but heavy metal content above the healthbased guidance in contaminated vegetables can pose a serious health risk to the millions of people who consume them. Therefore, it is important to assess these health risks. The risk assessment consists of hazard identification, hazard characterization, exposure assessment, and risk characterization [46]. Food legislation in the European Union includes both hazardand risk-based approaches for ensuring safety. In hazard-based approaches, simply the presence of a potentially harmful agent at a detectable level in food is used as a basis for legislation and risk management action. Risk-based approaches, on the other hand, try to establish health-based guidance values for human exposure to chemicals, such as acceptable or tolerable daily intakes, using toxicological data; estimates of human exposure are then compared with the health-based guidance value to assess whether there may be an unacceptable risk to health and whether risk management action is needed. Hazard- 
and risk-based approaches have a common element in that the identification of the hazard is a first step in both. In hazard-based approaches, the hazard may then be characterized. In risk-based approaches, this will be followed by exposure assessment and the integration of exposure with hazard characterization in the final risk characterization step, in order to provide an overall risk assessment, from which to conclude on safety [47].

Therefore, the aim of this study was to determine the content of heavy metals (Mn, $\mathrm{Zn}$, $\mathrm{Cr}, \mathrm{Cu}, \mathrm{Ni}, \mathrm{Cd}, \mathrm{Pb}$ and $\mathrm{Hg}$ ) in the soil as well as in selected varieties of the genus Capsicum grown in southern Slovakia and potential correlations among content of heavy metals in soil and content of heavy metals in studied species of genus Capsicum.

\section{Materials and Methods}

\subsection{Study Location and Sample Collection}

A small plot experiment was realized in the cadastral area of the village Imel'. The village of Imel' is located in southwestern Slovakia, lying in the Danubian Lowland between the rivers Nitra and Žitava (Figure 1). The territory of the village lies at an altitude of 108-121 m. The growing area belongs to the dry, warm climate zone (the average annual air temperature is $9.9^{\circ} \mathrm{C}$, and average annual rainfall is $550 \mathrm{~mm}$ ). The land in the cadastral territory of the municipality of Imel' consists mainly of black soils, which belong to the fertile lands, black earth soils, gley black soils, and modal carbonates. In flooded areas, fluvials are modal to gley. In the village, there are sandy soils suitable for growing chili peppers.

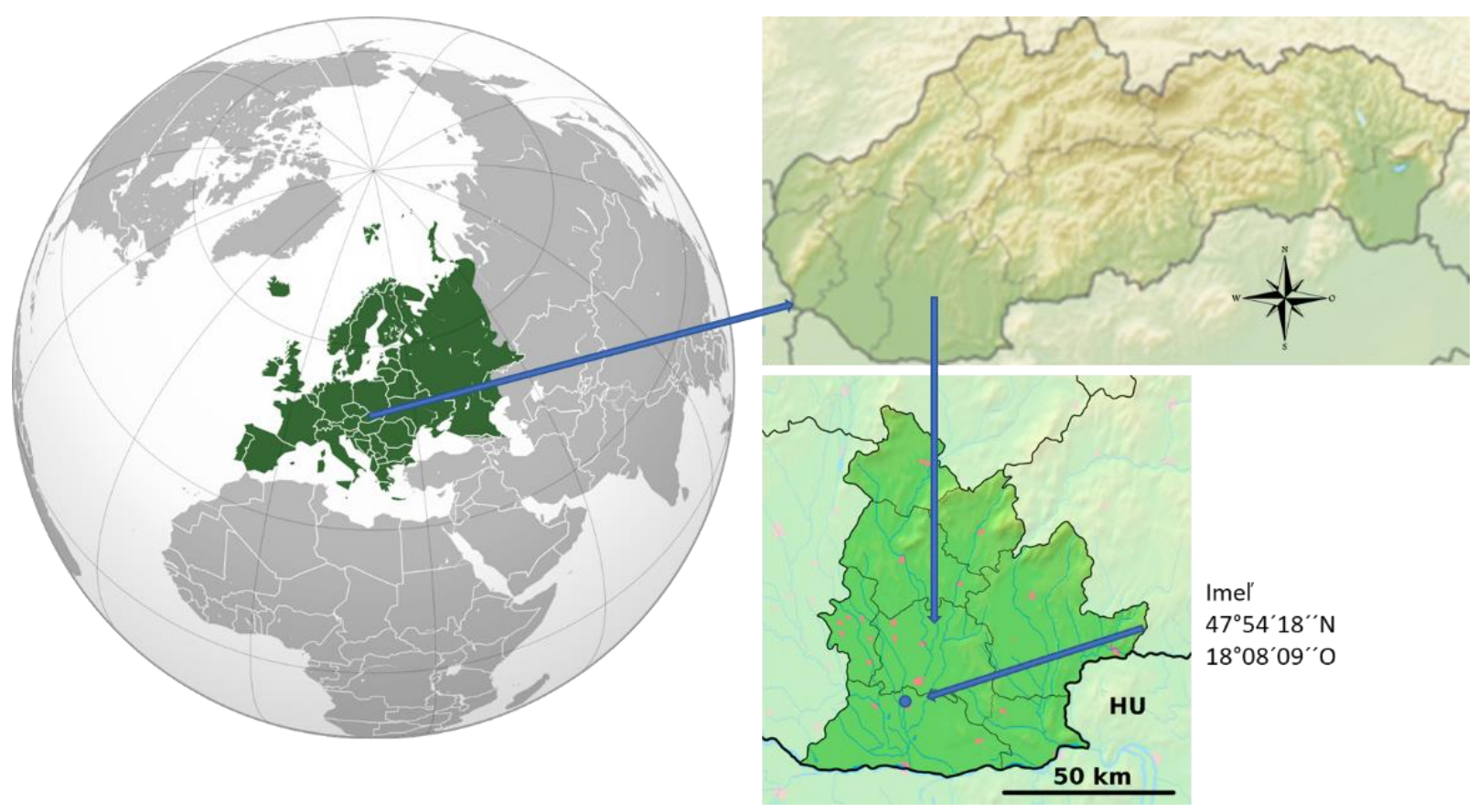

Figure 1. Map of small parcel experiment. Reproduced from [48], with permission from author, 2010, and from [49], with permission from author, 2010.

Eight samples of Capsicum (C. annuum L. and C. chinense L.), namely Sigaretta di Bergamo, Cayenne Long Slim, Chupetinho, Candlelight, Violet Cables, Scotch Bonet Yellow, Bhut Jolokia Red, Bhut Jolokia White, were obtained in this area. The investigated samples of Capsicum cultivars were conventionally cultivated in the same locality and under the same conditions. Only NPK fertilization was used to achieve a favorable content of macro elements in the soil.

The varieties of the chili peppers monitored were harvested by hand, after reaching full maturity in the growing season of the plant. The design of the experiment featured 
$10 \mathrm{~m}^{2}$ parcel for each cultivar. A total of $3 \mathrm{~kg}$ of representative sample were taken from 4 random places of every parcel. The samples were then cleaned, dried and homogenized, and used for analyses.

The determination of chili pepper dry matter was performed by drying at $105{ }^{\circ} \mathrm{C}$ to constant weight (WTC Binder, Tuttlingen, Germany). The samples were dried and afterwards homogenized on the grinder IKA A10 (IKA GmBH, Staufen, Germany). Prior to analyses, homogenized samples were stored in plastic bags. Soil samples were taken from 4 random places from the arable layer $(0-20 \mathrm{~cm})$ with a pedological probe GeoSampler (Bürkle $\mathrm{GmbH}$, Bad Belllingen, Germany). After collection, the soil samples were temporarily stored in plastic resealable bags. The soil samples were air dried at room temperature for 2 weeks, under laboratory conditions. They were then cleaned of coarse particles and sieved through a sieve (fine soil I-2 $\mathrm{mm}$ ), which was used to determine agrochemical characteristics. Fine soil II $(0.125 \mathrm{~mm})$ was used to determine the heavy metal content.

\subsection{Chemical Analysis of the Soil}

In each soil sample (4 samples for each analysis), the micronutrient content (Ca, $\mathrm{Mg}, \mathrm{K}, \mathrm{P})$ by Mehlich II, the exchangeable reactions $\left(\mathrm{pH} / \mathrm{CaCl}_{2}\right)$, and the organic carbon and humus content were determined [50,51]. Mobile forms of heavy metals (Mn, $\mathrm{Zn}, \mathrm{Cr}$, $\mathrm{Cu}, \mathrm{Ni}, \mathrm{Cd} \mathrm{Pb}$ ) and total heavy metal content $(\mathrm{Mn}, \mathrm{Zn}, \mathrm{Cr}, \mathrm{Cu}, \mathrm{Ni}, \mathrm{Cd}, \mathrm{Pb}, \mathrm{Hg}$ ) were also determined.

\subsubsection{Determination of $\left(\mathrm{pH} / \mathrm{CaCl}_{2}\right)$}

A total of $20 \mathrm{~g}$ of soil sample and $50 \mathrm{~mL}$ of $\mathrm{CaCl}_{2}$ (Sigma-Aldrich, Sigma-Aldrich, Inc., St. Loius, MO, USA) solution $\left(\mathrm{c}=0.01 \mathrm{~mol} / \mathrm{dm}^{3}\right)$ were mixed in a $100 \mathrm{~mL}$ plastic bottle and the substances were shaken for $20 \mathrm{~min}$ in a horizontal shaker Unimax 2010 (Heidolph Instrument, $\mathrm{GmbH}$, Schwabach, Germany). The samples were then filtered through quantitative filter paper Filtrak 390 (Munktell, GmbH, Bärenstein, Germany) and pH was determined with a pH meter Metrohm 691 (Metrohm, AG, Herisau, Switzerland).

\subsubsection{Determination of Humus Content and Content of Organic Carbon (Cox) in Soil}

A total of $1 \mathrm{~g}$ of fine soil II sample was mixed with $0.1 \mathrm{~g}^{\circ} \mathrm{Ag}_{2} \mathrm{SO}_{4}$ and $10 \mathrm{~mL}$ of a prearranged chromium-sulfur mixture. The flasks were heated to $150^{\circ} \mathrm{C}$ for $20 \mathrm{~min}$, during which the color changed from brown to yellowish orange. After cooling, samples were titrated with Mohr's salt solution ( $\left.c=0.1 \mathrm{~mol} / \mathrm{dm}^{3}\right)$ using an indicator (diphenylamine) [50,51].

\subsubsection{Determination of Available Micronutrients ( $\mathrm{Ca}, \mathrm{Mg}, \mathrm{K}, \mathrm{P})$ in Soil by Mehlich II}

At first, the Mehlich II solution was prepared. A total of $11.5 \mathrm{~mL}$ of glacial acetic acid was added to $10.7 \mathrm{~g}$ of NH4Cl; $0.56 \mathrm{~g} \mathrm{NH} 4 \mathrm{~F}$ and $1 \mathrm{~mL}$ concentrated $\mathrm{HCl}$ into a glass volumetric flask $(1000 \mathrm{~mL})$ and deionized water was added up to the mark. Amounts of $5 \mathrm{~g}$ of fine soil I and $50 \mathrm{~mL}$ of Mehlich II were weighed into a $100 \mathrm{~mL}$ plastic bottle, and mixed. The bottle was then shaken for $10 \mathrm{~min}$ on a horizontal shaker Unimax 2010 (Heidolph Instrument, GmbH, Schwabach, Germany). The samples were then filtered through quantitative filter paper Filtrak 390 (Munktell, GmbH, Bärenstein, Germany). The content of micronutrients $(\mathrm{Ca}, \mathrm{Mg}, \mathrm{K}$,) was determined by flame atomic absorption spectrometry-F-AAS — on a spectrometer SpectrAA 240FS (Varian Inc., Mulgrave, VIC, Australia). The phosphorus content was determined by pipetting $1 \mathrm{~mL}$ of the filtrate into a flask, adding $8 \mathrm{~mL}$ of solution $\mathrm{B}$ and making up the volume to $50 \mathrm{~mL}$ with deionized water. After $2 \mathrm{~h}$ of staining, the phosphorus content was determined by the Ultraviolet-visible scanning spectrometer Shimadzu UV-VIS 1800, $\lambda=666$ nm, (Shimadzu Corporation, Kyoto, Japan) [52].

\subsubsection{Determination of Total Heavy Metal Content in Soil}

The total heavy metal content was determined after mineralization in a $2.5 \mathrm{~mL} 65 \%$ HNO3 Suprapur ${ }^{\circledR}$ (Merck, Darmstadt, Germany) and 7.5 mL 37\% HCl Suprapur ${ }^{\circledR}$ (Merck, 
Darmstadt, Germany) mixture. This mixture is able to extract almost all heavy metals from the soil solution, with the exception of silicate and aluminosilicate soil grid structures.

The mineralization tubes were sealed and placed in a microwave digestion apparatus MarsX-press5 (CEM Corp., Matthews, NC, USA). The samples were filtered through quantitative filter paper Filtrak 390 (Munktell, GmbH, Bärenstein, Germany) and diluted with deionized water $(0.054 \mu \mathrm{S} / \mathrm{cm})$. For all procedures, high purity analytical reagents were used. The total heavy metal content was determined using the atomic absorption spectrometer SpectrAA 240FS (Varian Inc., Mulgrave, VIC, Australia) (Mn, Zn, Cu, Cr, $\mathrm{Ni}$ ) and the atomic absorption spectrometer SpectrAA $240 \mathrm{Z}(\mathrm{Cd}$ and $\mathrm{Pb})$ with Zeeman background correction. CertiPUR ${ }^{\circledR}$ (Merck, Darmstadt, Germany) calibration standard was used for calibration of the instruments.

The total $\mathrm{Hg}$ content was determined by the CV-AAS method on a selective $\mathrm{Hg}$ analyzer AMA-254 (Altec, Praque, Czech Republic.)

\subsubsection{Determination of Mobile Forms of Heavy Metals in Soil}

Mobile (available) forms of heavy metals, which are more accessible for plants, were determined by extracting $20 \mathrm{~g}$ of dried soil samples in $50 \mathrm{~mL}$ of $\mathrm{NH}_{4} \mathrm{NO}_{3}$ (SigmaAldrich, Inc., Saint-Loius, MO, USA) $\left(\mathrm{c}=1 \mathrm{~mol} / \mathrm{dm}^{3}\right)$ using a horizontal shaker Unimax 2010 (Heidolph Instrument, GmbH, Schwabach, Germany) for $2 \mathrm{~h}$. After extraction, the samples were filtered through quantitative filter paper Filtrak 390 (Munktell, GmbH, Bärenstein, Germany).

The content of mobile forms of heavy metals in soil was determined using the atomic absorption spectrometer SpectrAA 240FS (Varian Inc., Mulgrave, VIC, Australia) (Mn, Zn, $\mathrm{Cu}, \mathrm{Cr}, \mathrm{Ni}$ ) and atomic absorption spectrometer SpectrAA $240 \mathrm{Z}(\mathrm{Cd}$ and $\mathrm{Pb})$ with Zeeman background correction. CertiPUR ${ }^{\circledR}$ (Merck, Darmstadt, Germany) calibration standard was used for the calibration of the instruments.

The measured concentrations of selected heavy metals in soil samples were compared with Slovakian limit values, as given by Act No 220/2004, as well as with Threshold value given by the European Commission (2006).

\subsection{Chemical Analysis of the Plant Material}

Homogenized samples were mineralized in a mixture of $5 \mathrm{~mL}$ of $\mathrm{HNO}_{3}\left(\right.$ Suprapur $^{\circledR}$, Merck, Darmstadt, Germany) and $5 \mathrm{~mL}$ of deionized water $(0.054 \mu \mathrm{S} / \mathrm{cm})$ in the Mars Xpress 5 closed microwave digestion system (CEM Corp., Matthews, NC, USA). Digestive conditions for the microwave system used included heating at $160{ }^{\circ} \mathrm{C}$ for $15 \mathrm{~min}$ and maintaining it at a constant temperature for $10 \mathrm{~min}$. The digested material was then filtered through quantitative filter paper Filtrak 390 (Munktell, GmbH, Bärenstein, Germany) and filled to a volume of $50 \mathrm{~mL}$ with deionized water. Samples were analyzed by the atomic absorption spectrometer SpectrAA 240FS (Mn, Zn, Cu, Cr, Ni) (Varian Inc., Mulgrave, VIC, Australia) and atomic absorption spectrometer SpectrAA 240Z (Cd and Pb) with Zeeman background correction. The limit of detection for $\mathrm{Mb}, \mathrm{Zn}, \mathrm{Cu}, \mathrm{Cr}$, Ni was set at 3.0; 6.0; 2.0; 3.0; $8.0 \mu \mathrm{g} / \mathrm{kg}$, respectively, and for $\mathrm{Cd}$ and $\mathrm{Pb} 10.0,10.0 \mathrm{ng} / \mathrm{kg}$, respectively. The limit of quantification for $\mathrm{Mn}, \mathrm{Zn}, \mathrm{Cu}, \mathrm{Cr}, \mathrm{Ni}$ was set at 9.0; 18.0; 6.0;9.0; $24.0 \mu \mathrm{g} / \mathrm{kg}$, and for $\mathrm{Cd}$ and $\mathrm{Pb} 30.0$ and $30.0 \mathrm{ng} / \mathrm{kg}$, respectively.

The total $\mathrm{Hg}$ content was determined by the CV-AAS method on a selective $\mathrm{Hg}$ analyzer AMA-254 (Altec, Praque, Czech Republic) in all types of dried and homogenized samples. The limit of detection for $\mathrm{Hg}$ was set at $1.5 \mathrm{ng} / \mathrm{kg}$ dry weight (DW) and the limit of quantification at $4.45 \mathrm{ng} / \mathrm{kg}$ DW [53].

The content of heavy metals determined in plant samples were evaluated according to Decree no. 2/1994 Coll. Decree of the Ministry of Health of the Slovak Republic and maximum values according to Commission Regulation 1881/2006 (EC).

A description of analytical parameters for the determination of the elements is described in Table 1. 
Table 1. Validation parameters for determination of the elements.

\begin{tabular}{ccccc}
\hline Element & Wavelength $(\mathbf{n m})$ & LoD $(\mathbf{m g} / \mathbf{L})$ & LoQ $(\mathbf{m g} / \mathbf{L})$ & Recovery $(\%)$ \\
\hline $\mathrm{Mn}$ & 279.5 & 0.0250 & 0.0300 & 102.4 \\
$\mathrm{Zn}$ & 213.9 & 0.0870 & 0.1740 & 106.2 \\
$\mathrm{Cu}$ & 324.8 & 0.0876 & 0.0911 & 99.6 \\
$\mathrm{Cr}$ & 359.7 & 0.0300 & 0.050 & 92.2 \\
$\mathrm{Ni}$ & 232.0 & 0.3576 & 0.5646 & 104.9 \\
$\mathrm{~Pb}$ & 217.0 & 0.0894 & 0.1411 & 93.7 \\
$\mathrm{Cd}$ & 228.8 & 0.0621 & 0.1200 & 91.6 \\
$\mathrm{Hg}$ & 253.7 & $0.02 *$ & $0.04 *$ & 97.1 \\
\hline
\end{tabular}

* LoD limit of detection, LoQ limit of quantification, LoD and LoQ values for Hg expressed as nanograms per sample. Recovery was calculated for quality check of the solutions of known concentrations.

\subsection{Environmental and Health Risk Assessment}

We used the following parameters to evaluate the contamination of the soil where the monitored chili pepper varieties were grown:

The contamination factor $\left(C_{f}^{i}\right)$ is a quantification of the degree of contamination relative to either average crustal composition of a respective metal or to the measured background values from geologically similar and uncontaminated area [54]. It is expressed as a ratio of total content of heavy metal in soil $\left(\mathrm{C}_{\mathrm{s}}^{\mathrm{i}}\right)$ and their background values $\left(\mathrm{C}_{\mathrm{RefS}}\right)$ [55]

$$
C_{f}^{i}=\left(\frac{C_{s}^{i}}{C_{R e f S}}\right)
$$

For the calculation of $C_{\mathrm{f}}^{\mathrm{i}}$, the background values from soil monitoring of the Slovak Republic [56] were used.

Based on the contamination factor, soil is characterized as follows: $\mathrm{C}_{\mathrm{f}}^{\mathrm{i}}<1$ : low contamination, $3<\mathrm{C}_{\mathrm{f}}^{\mathrm{i}}<6$ : considerable contamination, $\mathrm{C}_{\mathrm{f}}^{\mathrm{i}}>6$ : very high contamination [55].

The degree of contamination $\left(\mathrm{C}_{\mathrm{deg}}\right)$ is the sum of contamination factors for all monitored risk elements and is calculated based on the relationship:

$$
\mathrm{C}_{\mathrm{deg}}=\sum \mathrm{C}_{\mathrm{f}}^{\mathrm{i}}
$$

The sum of $\mathrm{C}_{\mathrm{f}}^{\mathrm{i}}$ for all metals represents an integrated degree of environmental pollution $[57,58]$. Based on the degree of contamination, soil is characterized as it follows: $\mathrm{C}_{\mathrm{deg}}<5$ : low contamination, $5 \mathrm{C}_{\mathrm{deg}}<10$ : moderate contamination, $10 \leq \mathrm{C}_{\mathrm{deg}}<20$ : considerable contamination, $C_{\text {deg }} \geq 20$ : high contamination [55].

The potential ecological risk factor $\left(E_{\mathrm{r}}^{\mathrm{i}}\right)$ is used to evaluate the toxicity of the monitored elements. Its calculation is based on the relationship:

$$
\mathrm{E}_{\mathrm{r}}^{\mathrm{i}}=\mathrm{T}_{\mathrm{r}}^{\mathrm{i}} \times \mathrm{C}_{\mathrm{f}}^{\mathrm{i}}
$$

$\mathrm{T}_{\mathrm{r}}^{\mathrm{i}}$ - the biological toxic factor of each element. In particular, the toxic factor should provide information on potential modes of transport of toxic substances to humans and on human hazards [30]. Based on the potential ecological risk factor, soil is characterized as follows: $\mathrm{E}_{\mathrm{r}}^{\mathrm{i}}<40$ : low risk, $40 \leq \mathrm{E}_{\mathrm{r}}^{\mathrm{i}}<80$ : moderate risk, $80 \leq \mathrm{E}_{\mathrm{r}}^{\mathrm{i}}<160$ : considerable risk, $160 \leq \mathrm{E}_{\mathrm{r}}^{\mathrm{i}}<320$ : high risk, $\mathrm{E}_{\mathrm{r}}^{\mathrm{i}}>320$ : very high risk [57].

The index of geoaccumulation ( $\mathrm{I}_{\text {geo }}$ ) is used to quantify the degree of the contamination of an individual element. It is calculated according to the formula:

$$
\mathrm{I}_{\text {geo }}=\log _{2}\left(\frac{\mathrm{C}^{\mathrm{i}}}{1.5 \times \mathrm{B}^{\mathrm{i}}}\right)
$$


where $C^{i}$ is the concentration of heavy metal in soil and $B^{i}$ the background values from soil monitoring of the Slovak Republic [56]. Soil contamination on the basis of soil using the index of geoaccumulation is characterized as follows: $\mathrm{I}_{\text {geo }}=0$ : no contamination, $0 \leq \mathrm{I}_{\text {geo }} \leq 1$ : light contamination, $1 \leq \mathrm{I}_{\text {geo }} \leq 2$ : slightly moderate contamination, $2 \leq \mathrm{I}_{\text {geo }} \leq 3$ : moderate contamination, $3 \leq \mathrm{I}_{\text {geo }} \leq 4$ : slightly heavy contamination, $4 \leq \mathrm{I}_{\text {geo }} \leq 5$ : heavy contamination, $\mathrm{I}_{\text {geo }} \leq 5$ : extremely heavy contamination [59].

The pollution load index (PLI) serves to assess soil quality in terms of hazardous risk elements. It is defined as the $n$th root of the product of contamination factors $\left(C_{f}^{i}\right)[58,60]$, and is calculated according to the relation:

$$
\mathrm{PLI}=\left(\mathrm{C}_{\mathrm{f} 1}^{\mathrm{i}} \times \mathrm{C}_{\mathrm{f} 2}^{\mathrm{i}} \times \mathrm{C}_{\mathrm{f} 3}^{\mathrm{i}} \times \ldots \times \mathrm{C}_{\mathrm{f} n}^{\mathrm{i}}\right)^{\frac{1}{n}}
$$

The bioaccumulation factor (BAF) is defined as the ratio of the content of the monitored heavy metal in the plant material in relation to the content in the soil [61], and reflects the ability of the plant to absorb heavy metal. The BAF was calculated as follows:

$$
\mathrm{BAF}=\frac{\text { total heavy metal } \in \text { dried plant materials }}{\text { total heavy metals } \in \text { dried soil samples }}
$$

The provisional tolerable intake (PMTDI, PTWI, PTMI) estimates the amount per unit body weight of a potentially harmful substance or contaminant in food or water that can be ingested over a lifetime without risk of adverse health effects. JECFA uses the term PTWI, or provisional tolerable daily intake, for contaminants that may accumulate in the body. The weekly designation is used to stress the importance of limiting intake over a period of time for such substance [62]. The provisional tolerable weekly intake (PTWI) is the end-point used by the Joint FAO/WHO Expert Committee on Food Additives for food contaminants such as heavy metals with cumulative properties. Its value represents the permissible human weekly exposure to those contaminants unavoidably associated with the consumption of otherwise wholesome and nutritious foods.

The provisional tolerable monthly intake (PTMI) is an end-point used by the Joint FAO/WHO Expert Committee on Food Additives for a food contaminant with cumulative properties that has a very long half-life in the human body. Its value represents the permissible human monthly exposure to a contaminant unavoidably associated with otherwise wholesome and nutritious foods. The provisional maximum tolerable daily intake (PMTDI) is the reference value, established by the Joint FAO/WHO Expert Committee on Food Additives, used to indicate the safe level of intake of a contaminant with no cumulative properties. Its value represents permissible human exposure as a result of the natural occurrence of the substance in food and drinking water. In the case of trace elements that are both essential nutrients and unavoidable constituents of food, a range is expressed, the lower value representing the level of essentiality and the upper value the PMTDI. The tolerable intake is generally referred to as "provisional", as there is often a paucity of data on the consequences of human exposure at low levels, and new data may result in a change to the tolerable level [63].

The daily consumption of chili pepper can be as high as $15 \mathrm{~g}$ per person in Mexico and Korea. At the other end of the spectrum are the Northern European countries where the daily chili pepper consumption is less than $1 \mathrm{~g}$ per person [64]. According to FAOSTAT, consumption of green peppers and chilies in Slovakia represent $12 \mathrm{~g} / \mathrm{capita} /$ day. The estimated chili pepper consumption in Slovakia is $1 \mathrm{~g} /$ day/per capita.

The tolerable intakes for $\mathrm{Cd}, \mathrm{Pb}, \mathrm{Hg}, \mathrm{Cu}$ and $\mathrm{Zn}$ is established by WHO.

The limit values of $(\mathrm{Zn}, \mathrm{Ni}, \mathrm{Cu}, \mathrm{Cd}, \mathrm{Pb}, \mathrm{Hg})$ for soil was evaluated according to legislation valid in the Slovak Republic (Act number 220/2004) together with the threshold value of $(\mathrm{Zn}, \mathrm{Ni}, \mathrm{Cu}, \mathrm{Cd}, \mathrm{Pb})$ according to the European Commission (2006).

The limit values of $(\mathrm{Zn}, \mathrm{Cu}, \mathrm{Cr}, \mathrm{Ni}, \mathrm{Cd}, \mathrm{Pb}, \mathrm{Hg})$ in plant matter was evaluated according to the Food Codex of the Slovak Republic, and the maximal level of $(\mathrm{Cd}, \mathrm{Pb})$ according to Commission Regulation 1881/2006(EC). 


\subsection{Statistical Analysis}

At first, all variables were tested for normality. All the tested variables did not follow the normal distribution according to the Shapiro-Wilk test and Kolmogorov-Smirnov test; therefore, Kruskal-Wallis (nonparametric ANOVA) and Wilcoxon tests were performed to find the significant differences between the tested variables. For a better understanding and interpretation of the results, each cultivar was compared with the median value (horizontal line) using the Wilcoxon test. The Spearman correlation test at the significance level $\alpha=0.05$ was used to analyze the relationships between the variables. Principal component analysis was performed to summarize and to visualize the information in a dataset. Descriptive statistics, normality tests, and the principal component analysis were performed using MS Excel with the XLSTAT package [65]. Kruskal-Wallis and Wilcoxon tests were performed in RStudio software, version 1.2.5033 [66].

\section{Results and Discussion}

\subsection{Agrochemical Characteristics, Contents of Nutrients and Heavy Metals in Soil}

Agrochemical characteristics, and contents of nutrients in soil from the cultivation locality Imel' are presented in Table 2.

Table 2. Agrochemical characteristic of soil of the cultivation area in $\mathrm{mg} / \mathrm{kg}$ (as a mean of 4 realized analyses, no samples were excluded).

\begin{tabular}{ccccccccc}
\hline & $\mathbf{C a}$ & $\mathbf{K}$ & $\mathbf{M g}$ & $\mathbf{P}$ & $\mathbf{N}_{\text {an }}$ & $\mathbf{p H} / \mathbf{C a C l}_{\mathbf{2}}$ & $\mathbf{H u m u s}_{\mathbf{( \% )}}$ & $\mathbf{C}_{\mathbf{O X}}(\mathbf{\%})$ \\
\hline Min & 3879 & 139.15 & 305.68 & 168 & 43.9 & 7.47 & 3.06 & 1.77 \\
Max & 4150 & 147.12 & 338.15 & 180 & 46.34 & 7.63 & 3.17 & 1.83 \\
Median & 3975.5 & 143.065 & 316.46 & 173 & 45.08 & 7.55 & 3.085 & 1.8 \\
Average & 3995 & 143.1 & 319.19 & 174 & 45.1 & 7.55 & 3.1 & 1.8 \\
STDEV & 112.91 & 3.28 & 13.95 & 5.67 & 1.21 & 0.07 & 0.05 & 0.03 \\
\hline
\end{tabular}

The $\mathrm{pH}$ of the soil of the monitored land has an average value of $7.55 \pm 0.07$, which can be characterized as alkaline and moderately humic, with humus content of $3.10 \%$. The soil was characterized by a medium content of potassium and a very high content of phosphorus and magnesium $(\mathrm{P}=174 \mathrm{mg} / \mathrm{kg}, \mathrm{Mg}=319 \mathrm{mg} / \mathrm{kg})$.

In this work, we determined the total content of heavy metals in the soil and compared the values of heavy metals with the limit value-for a soil extract by aqua regia according to legislation valid in the Slovak Republic (Act number 220/2004) as well as with the threshold value-European Commission (2006). The higher content of heavy metals in the soil could be reflected in the quality of cultivated crops, followed by accumulation in the aboveground mass. Based on their physiological purpose, heavy metals are divided into non-essential and essential heavy metals. While essential heavy metals ( $\mathrm{Fe}, \mathrm{Cu}, \mathrm{Zn}, \mathrm{Mn}$ ) are relatively less toxic and in certain concentrations are needed for healthy plant growth and development, non-essential heavy metals $(\mathrm{Cd}, \mathrm{Pb}, \mathrm{As}, \mathrm{Hg})$ are highly toxic for plants and humans, even at low-level concentrations [9]. The total heavy metal content in the soil from the crop growing locality Imel' is presented in Table 3.

We can state that out of the total content of heavy metals in the mentioned soil, the limit value of the Cd content (according to the legislation valid in the Slovak Republic, Act number 220/2004) was exceeded 2.34 times and represented the value of $1.64 \mathrm{mg} / \mathrm{kg}$. Additionally, the threshold value given by the European Commission (EC) (2006) was exceeded. Other analyzed heavy metals in soil did not exceed the limit values. The presence and toxicity of risk elements in the soil is a major threat, as they can seriously damage human health through the food chain [67]. 
Table 3. Total content of heavy metals ( $\mathrm{Ci}-\mathrm{CMn}, \mathrm{CZn}, \mathrm{CCr}, \mathrm{CCu}, \mathrm{CNi}, \mathrm{CCd}, \mathrm{CPb}, \mathrm{CHg}$ ) in soil in mg/kg (as a mean of 4 realized analyses, no samples were excluded).

\begin{tabular}{|c|c|c|c|c|c|c|c|c|}
\hline & Mn & $\mathrm{Zn}$ & $\mathrm{Cr}$ & $\mathrm{Cu}$ & $\mathbf{N i}$ & $\mathrm{Cd}$ & $\mathrm{Pb}$ & $\mathrm{Hg}$ \\
\hline Minimum & 333.65 & 77.5 & 7.52 & 28.88 & 12.92 & 1.59 & 13.89 & 0.0125 \\
\hline Maximum & 345.23 & 79.1 & 7.90 & 30.78 & 13.73 & 1.68 & 14.7 & 0.0132 \\
\hline Median & 341.76 & 78.1 & 7.69 & 29.98 & 13.27 & 1645 & 14.29 & 0.0128 \\
\hline Average & 340.6 & 78.2 & 7.7 & 29.9 & 13.3 & 1.64 & 14.30 & 0.013 \\
\hline STDEV & 4.95 & 0.66 & 0.16 & 0.79 & 0.36 & 0.037 & 0.42 & 0.0003 \\
\hline $\begin{array}{c}\text { Contamination factor } \\
\qquad\left(C_{f}^{i}\right)\end{array}$ & 0.85 & 1.10 & 0.22 & 1.19 & 0.67 & 16.4 & 0.72 & 0.16 \\
\hline $\begin{array}{l}\text { Potential ecological risk } \\
\text { factor }\left(E_{\mathrm{r}}^{\mathrm{i}}\right)\end{array}$ & 0.85 & 1.10 & 0.44 & 5.98 & 3.33 & 492 & 3.57 & 6.41 \\
\hline $\begin{array}{l}\text { Geoaccumulation Index } \\
\qquad\left(\mathrm{I}_{\mathrm{geo}}\right)\end{array}$ & -0.82 & -0.44 & -2.77 & -0.33 & -1.17 & 3.45 & -1.07 & -3.23 \\
\hline Limit value & & 150 & & 60.0 & 50.0 & 0.70 & 70 & 0.50 \\
\hline Threshold value & & 100 & & 40.00 & 30.0 & 0.50 & 50 & \\
\hline
\end{tabular}

Limit value-for a soil extract by aqua regia according to legislation valid in the Slovak Republic (Act number 220/2004), threshold value-European Commission (2006).

The nature of soil contamination can be described by factors such as the contamination factor $\left(C_{f}^{i}\right.$ and degree of contamination $\left(C_{d e g}\right)$ [30]. The average $C_{f}^{i}$ values for heavy metals $(\mathrm{Mn}, \mathrm{Zn}, \mathrm{Cr}, \mathrm{Cu}, \mathrm{Ni}, \mathrm{Cd}, \mathrm{Pb}$ and $\mathrm{Hg}$ ) are in the range from $0.16(\mathrm{Hg})$ to $16.4(\mathrm{Cd})$. Based on cf values, we can state that the soil is weakly contaminated by $\mathrm{Mn}, \mathrm{Cr}, \mathrm{Ni}, \mathrm{Pb}$, and $\mathrm{Hg}$ $\left(C_{\mathrm{f}}^{\mathrm{i}}<1\right)$, moderately contaminated by $\mathrm{Zn}$ and $\mathrm{Cu}\left(1<\mathrm{C}_{\mathrm{f}}^{\mathrm{i}}<3\right)$ and very highly contaminated by $\mathrm{Cd}\left(\mathrm{C}_{\mathrm{f}}^{\mathrm{i}}>6\right)$. The degree of contamination $\left(\mathrm{C}_{\mathrm{deg}}\right)$ is another parameter that indicates the degree of soil contamination by all risk elements. The degree of contamination for our land is 21.31. The monitored soil can be characterized as the soil with the highest degree of contamination $\left(\mathrm{C}_{\mathrm{deg}} \geq 20\right)$ [57].

We also determined the potential ecological risk factor $\left(E_{r}^{i}\right)$ for each monitored heavy metal. This parameter is related not only to the concentration of the given risk element in the soil but also to the toxicity of each element. The values determined on the basis of the total content of risk element are given in Table 3. All monitored heavy metals except $\mathrm{Cd}$ had this parameter less than $40\left(\mathrm{E}_{\mathrm{r}}^{\mathrm{i}}<40\right)$. For $\mathrm{Cd}$, this parameter was 492 . Based on these values, we can characterize the soil as highly contaminated with $\mathrm{Cd}$ and weakly contaminated with other heavy metals ( $\mathrm{Mn}, \mathrm{Zn}, \mathrm{Cr}, \mathrm{Cu}, \mathrm{Ni}, \mathrm{Pb}$ and $\mathrm{Hg}$ ) [57,58].

Based on the index of geoaccumulation $\left(\mathrm{I}_{\text {geo }}\right)$, soils are classified into seven classes $[59,68]$. The average values of the $I_{\text {geo }}$ of the monitored soil were in the range of -3.23 to 3.45 . The soil sample had an $\mathrm{I}_{\text {geo }}$ value $<0$ (background values for, $\mathrm{Mn}, \mathrm{Zn}, \mathrm{Cr}, \mathrm{Cu}, \mathrm{Ni}, \mathrm{Cd}, \mathrm{Pb}, \mathrm{Hg}$ ) and a value to $\mathrm{I}_{\text {geo }}>3$ (moderately contaminated for $\mathrm{Cd}$ ).

The contamination of soil with heavy metals is assessed in terms of the risks arising from possible penetration into plants and the whole food chain. Bioavailable forms of heavy metals in the soil are very important for the assessment and prognosis of crop contamination. The high availability of heavy metals threatens the environment more than their total soil content [69]. Heavy metals can migrate into soil ecosystems and subsequently seriously damage human and animal health. The mobility and bioavailability of heavy metals depend on the chemical, physical, biological and microbiological properties of the soil. Factors that affect the bioavailability of metals include $\mathrm{pH}$, and organic matter content $[70,71]$. It also depends on the mechanisms of absorption, the oxidation state of the metals present, soil cation exchange capacity, nature, the presence of other nutrients in the soil, soil salinity, but also the climate, which can significantly affect the availability of metals in the soil $[68,72,73]$. The phytotoxicity of heavy metals is manifested mainly on acidic soils. Plants that are short, less than a meter in length and have a large surface leaf, are more sensitive to the absorption of heavy metals [74]. The content of bioavailable forms of heavy metals in the soil from the crop growing locality Imel' is presented in the Table 4. 
Table 4. Content of bioavailable forms of heavy metals ( $\mathrm{Mn}, \mathrm{Zn}, \mathrm{Cr}, \mathrm{Cu}, \mathrm{Ni}, \mathrm{Cd}, \mathrm{Pb}$ ) in soil in $\mathrm{mg} / \mathrm{kg}$ (as a mean of 4 realized analyses, no samples were excluded).

\begin{tabular}{cccccccc}
\hline & $\mathbf{M n}$ & $\mathbf{Z n}$ & $\mathbf{C r}$ & $\mathbf{C u}$ & $\mathbf{N i}$ & $\mathbf{C d}$ & $\mathbf{P b}$ \\
\hline Minimum & 0.14 & 0.18 & 0.03 & 0.19 & 0.14 & 0.1 & 0.24 \\
Maximum & 0.18 & 0.21 & 0.07 & 0.24 & 0.18 & 0.14 & 0.28 \\
Median & 0.16 & 0.185 & 0.05 & 0.225 & 0.16 & 0.12 & 0.26 \\
Average & 0.16 & 0.19 & 0.05 & 0.22 & 0.16 & 0.12 & 0.26 \\
STDEV & 0.018 & 0.014 & 0.018 & 0.022 & 0.018 & 0.018 & 0.018 \\
Critical value & & 2.00 & & 1.00 & 1.50 & 0.10 & 0.10
\end{tabular}

Critical value-for a soil extract by $\mathrm{NH}_{4} \mathrm{NO}_{3}$ according to legislation valid in the Slovak Republic (Act number 220/2004).

Of the monitored bioavailable forms of heavy metals specified in $1 \mathrm{M} \mathrm{NH}_{4} \mathrm{NO}_{3}$, the critical value according to the legislation valid in the Slovak Republic (Act number $220 / 2004$ ) was exceeded for $\mathrm{Cd}$ and $\mathrm{Pb}$. We can state that high concentrations of bioavailable forms of $\mathrm{Cd}$ and $\mathrm{Pb}$ are risky. In the case of $\mathrm{Cd}$, the critical value was exceeded 1.2 times, and in the case of $\mathrm{Pb}$, this value was exceeded 2.6 times.

The contents of $\mathrm{Zn}, \mathrm{Cu}$ and $\mathrm{Ni}$ in their bioavailable forms were lower than the critical values set for these elements. Food crops as well as peppers can absorb individual elements from contaminated soil, wastewater used for irrigation as well as from sediments on various parts of vegetables from a polluted environment, which can lead to food contamination and consequently significant risks to human health [75].

For this reason, it is very necessary to carry out constant monitoring of heavy metals in edible parts of plants. Due to the frequent consumption of vegetables, it is very necessary to ensure that the level of these contaminants meets the agreed requirements. The levels of heavy metals ( $\mathrm{Mn}, \mathrm{Zn}, \mathrm{Cr}, \mathrm{Cu}, \mathrm{Ni}, \mathrm{Cd}, \mathrm{Pb}$ and $\mathrm{Hg}$ ) in the chili pepper samples are shown in Tables 5 and 6.

\subsection{Concentration of Heavy Metals in Plant Samples}

Of the essential heavy metals required by the human body in certain low concentrations, we monitored $\mathrm{Mn}, \mathrm{Zn}$ and $\mathrm{Cu}$ in selected varieties of chili peppers. The determined values of Mn content ranged from 1.26 to $2.73 \mathrm{mg} / \mathrm{kg}$ FW and the values of $\mathrm{Zn}$ content were determined from 1.12 to $2.73 \mathrm{mg} / \mathrm{kg}$ FW. The Food Codex of the SR as well as Commission Regulation 1881/2006 (EC) do not specify a limit value for Mn. The limit value for the $\mathrm{Zn}$ content in none of the analyzed pepper varieties was exceeded. Assuming that a $70 \mathrm{~kg}$ adult consumes $1 \mathrm{~g}$ of chili pepper with the highest $\mathrm{Zn}$ content $(0.42 \mathrm{mg} / \mathrm{kg})$ per day, the daily intake of $\mathrm{Zn}$ from chili peppers is $0.00273 \mathrm{mg}$, which is below the PTMI (21-70 mg/70 kg).

Some of heavy metals such as $\mathrm{Cu}, \mathrm{Co}, \mathrm{Fe}, \mathrm{Ni}, \mathrm{Mn}, \mathrm{Mo}, \mathrm{Cr}, \mathrm{Se}, \mathrm{Mg}$ and $\mathrm{Zn}$ have functional roles which are essential for various diverse physiological and biochemical activities in the body and may result in deficiency diseases or syndromes if there are inadequate amounts in the body but in large doses they may cause acute or chronic toxicities [76]. 
Table 5. Total content of heavy metals in Capsicum samples in $\mathrm{mg} / \mathrm{kg}$ fresh weight (as a mean of 4 realized analyses, no samples were excluded).

\begin{tabular}{|c|c|c|c|c|c|c|c|c|}
\hline $\mathrm{mg} / \mathrm{kg}$ FW & Mn & $\mathrm{Zn}$ & $\mathrm{Cr}$ & $\mathrm{Cu}$ & $\mathrm{Ni}$ & $\mathrm{Cd}$ & $\mathrm{Pb}$ & $\mathrm{Hg}$ \\
\hline & & & & C. апnиuт & & & & \\
\hline 1. Sigaretta di & $1.32 \pm 0.19$ & $1.95 \pm 0.25$ & $0.23 \pm 0.03$ & $1.35 \pm 0.15$ & $0.23 \pm 0.03$ & $0.06 \pm 0.003$ & $0.36 \pm 0.04$ & $0.00003 \pm 0.000005$ \\
\hline $\begin{array}{l}\text { Bergamo } \\
\text { MINIMUM }\end{array}$ & 1.13 & 1.62 & 0.19 & 1.16 & 0.21 & 0.061 & 0.31 & 0.000025 \\
\hline MAXIMUM & 1.54 & 2.23 & 0.25 & 1.52 & 0.27 & 0.068 & 0.41 & 0.000036 \\
\hline BAF & 0.017 & 0.112 & 0.131 & 0.201 & 0.076 & 0.177 & 0.112 & 0.01 \\
\hline 2. Cayenne Long Slim & $1.61 \pm 0.19$ & $1.39 \pm 0.15$ & $0.12 \pm 0.02$ & $0.82 \pm 0.10$ & $0.16 \pm 0.02$ & $0.02 \pm 0.003$ & $0.10 \pm 0.02$ & $0.00003 \pm 0.00001$ \\
\hline MINIMUM & 1.42 & 1.22 & 0.10 & 0.70 & 0.14 & 0.012 & 0.08 & 0.000017 \\
\hline MAXIMUM & 1.79 & 1.58 & 0.14 & 0.94 & 0.18 & 0.018 & 0.12 & 0.000042 \\
\hline MEDIAN & 1.61 & 1.37 & 0.12 & 0.83 & 0.16 & 0.017 & 0.10 & 0.000028 \\
\hline BAF & 0.024 & 0.088 & 0.079 & 0.138 & 0.06 & 0.049 & 0.036 & 0.011 \\
\hline MINIMUM & 2.27 & 2.30 & 0.09 & 1.48 & 0.05 & 0.035 & $\begin{array}{l}0.11 \\
0.11\end{array}$ & 0.000161 \\
\hline MAXIMUM & 2.99 & 3.18 & 0.14 & $\begin{array}{l}1.40 \\
2.04\end{array}$ & 0.08 & 0.043 & 0.16 & 0.000207 \\
\hline MEDIAN & 2.84 & 2.73 & 0.11 & 1.74 & 0.07 & 0.036 & 0.13 & 0.000184 \\
\hline BAF & 0.026 & 0.082 & 0.103 & 0.125 & 0.03 & 0.116 & 0.056 & 0.042 \\
\hline 4. Violet Cables & $2.24 \pm 0.36$ & $1.66 \pm 0.20$ & $0.19 \pm 0.02$ & $0.77 \pm 0.07$ & $0.10 \pm 0.01$ & $0.05 \pm 0.007$ & ND & $0.0001 \pm 0.00003$ \\
\hline MINIMUM & 1.84 & 1.41 & 0.16 & 0.68 & 0.09 & 0.039 & ND & 0.000069 \\
\hline MAXIMUM & 2.63 & 1.90 & 0.21 & 0.86 & 0.12 & 0.056 & ND & 0.000121 \\
\hline MEDIAN & 2.24 & 1.66 & 0.19 & 0.77 & 0.10 & 0.047 & ND & 0.000111 \\
\hline BAF & 0.033 & 0.105 & 0.121 & 0.128 & 0.039 & 0.140 & ND & 0.039 \\
\hline 5. Chupetinho & $2.34 \pm 0.34$ & $1.73 \pm 0.23$ & $0.20 \pm 0.02$ & $\begin{array}{l}\text { C. chinense } \\
1.14 \pm 0.12\end{array}$ & $0.08 \pm 0.01$ & $0.01 \pm 0.002$ & $0.04 \pm 0.01$ & $0.00045 \pm 0.00013$ \\
\hline MINIMUM & & & $\begin{array}{l}0.20 .17 \\
0.17\end{array}$ & $\begin{array}{l}1.141 .12 \\
0.99\end{array}$ & 0.06 & 0.004 & $\begin{array}{l}.07 .03 \\
0.03\end{array}$ & 0.000269 \\
\hline MAXIMUM & 2.70 & 2.04 & 0.22 & & 0.09 & 0.008 & 0.05 & 0.000566 \\
\hline MEDIAN & 2.35 & 1.69 & 0.20 & 1.14 & 0.08 & 0.006 & 0.04 & 0.000491 \\
\hline $\begin{array}{l}\text { Yellow } \\
\text { MINIMUM }\end{array}$ & 2.18 & 1.76 & 0.20 & 0.95 & 0.10 & 0.047 & 0.20 & 0.000073 \\
\hline MAXIMUM & 3.10 & 2.03 & 0.26 & 1.22 & 0.13 & 0.060 & 0.27 & 0.000220 \\
\hline MEDIAN & 2.64 & 1.89 & 0.23 & 1.10 & 0.12 & 0.058 & 0.23 & 0.000176 \\
\hline BAF & 0.037 & 0.119 & 0.140 & 0.205 & 0.032 & 0.018 & 0.015 & 0.188 \\
\hline 7. Bhut Jolokia Red & $2.01 \pm 0.28$ & $1.68 \pm 0.21$ & $0.18 \pm 0.03$ & $0.95 \pm 0.12$ & $0.15 \pm 0.02$ & $0.01 \pm 0.002$ & $0.15 \pm 0.02$ & $0.00003 \pm 0.000004$ \\
\hline MINIMUM & $\begin{array}{l}2.01 \pm 0.20 \\
1.79\end{array}$ & $\begin{array}{c}1.00 \pm 0.21 \\
1.43\end{array}$ & $\begin{array}{l}0.10 \pm 0.03 \\
0.15\end{array}$ & $\begin{array}{l}0.78 \\
0.78\end{array}$ & $\begin{array}{l}0.10 .02 \\
0.13\end{array}$ & 0.002 & $\begin{array}{l}0.10 \pm 0.13 \\
0.13\end{array}$ & 0.000020 \\
\hline MAXIMUM & 2.41 & $\begin{array}{l}1.43 \\
1.93\end{array}$ & 0.22 & $\begin{array}{l}0.05 \\
1.05\end{array}$ & 0.17 & 0.008 & 0.17 & 0.000031 \\
\hline MEDIAN & 1.93 & 1.68 & 0.17 & 0.98 & 0.15 & 0.005 & 0.15 & 0.000026 \\
\hline BAF & 0.030 & 0.120 & 0.130 & 0.178 & 0.06 & 0.018 & 0.058 & 0.011 \\
\hline 8. Bhut Jolokia White & $1.26 \pm 0.22$ & $1.12 \pm 0.12$ & $0.21 \pm 0.02$ & $0.70 \pm 0.08$ & $0.17 \pm 0.02$ & $0.08 \pm 0.010$ & $0.42 \pm 0.05$ & $0.00012 \pm 0.00002$ \\
\hline MINIMUM & 1.06 & 0.98 & 0.19 & 0.60 & 0.15 & 0.072 & 0.38 & 0.000103 \\
\hline MAXIMUM & 1.46 & 1.26 & 0.24 & 0.79 & 0.19 & 0.095 & 0.48 & 0.000141 \\
\hline MEDIAN & 1.26 & 1.12 & 0.20 & 0.71 & 0.17 & 0.080 & 0.41 & 0.000122 \\
\hline & 0.020 & 0.076 & 0.143 & 0.125 & 0.068 & 0.262 & 0.086 & \\
\hline \multirow{2}{*}{$\begin{array}{c}\text { Limit } \\
\text { Maximal level }\end{array}$} & & 10.0 & 0.2 & 10.0 & 0.50 & 0.05 & 0.5 & 0.02 \\
\hline & & PMTDI 0 3-1 & & PMTDI 0.5 & & $\begin{array}{l}0.05 \\
\text { PTMI } 02025\end{array}$ & $\begin{array}{l}0.10 \\
\text { PTMI } 0.025\end{array}$ & PTWI 0.004 \\
\hline
\end{tabular}

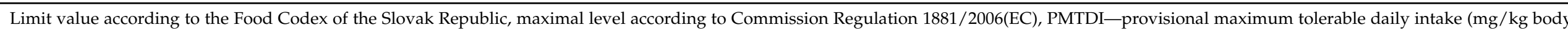

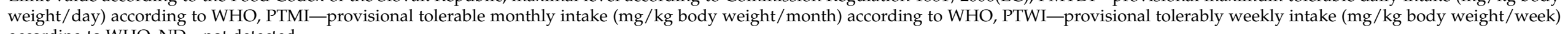
according to WHO. ND-not detected 
Table 6. Total content of heavy metals in Capsicum samples in $\mathrm{mg} / \mathrm{kg}$ dry matter (as a mean of 4 realized analyses, no samples were excluded).

\begin{tabular}{|c|c|c|c|c|c|c|c|c|}
\hline $\mathrm{mg} / \mathrm{kg} \mathrm{DM}$ & Mn & $\mathrm{Zn}$ & $\mathrm{Cr}$ & $\mathrm{Cu}$ & $\mathrm{Ni}$ & $\mathrm{Cd}$ & $\mathbf{P b}$ & $\mathrm{Hg}$ \\
\hline \multicolumn{9}{|c|}{ С. аппиит } \\
\hline $\begin{array}{l}\text { 1. Sigaretta di } \\
\text { Bergamo }\end{array}$ & $5.91 \pm 0.85^{\mathrm{a}}$ & $8.72 \pm 1.11^{\mathrm{a}}$ & $1.01 \pm 0.12^{\mathrm{a}}$ & $6.01 \pm 0.65^{\mathrm{a}}$ & $1.01 \pm 0.13^{\mathrm{a}}$ & $0.29 \pm 0.01^{\mathrm{a}}$ & $1.61 \pm 0.19^{\mathrm{a}}$ & $0.00013 \pm 0.00002^{a}$ \\
\hline MINIMUM & 5.06 & 7.25 & 0.83 & 5.20 & 0.92 & 0.27 & 1.39 & 0.00011 \\
\hline MAXIMUM & 6.88 & 9.94 & 1.11 & 6.78 & 1.19 & 0.30 & 1.81 & 0.000159 \\
\hline \multirow{2}{*}{$\begin{array}{l}\text { 2. Cayenne Long } \\
\text { Slim }\end{array}$} & 5.85 & 8.85 & 1.05 & 6.04 & 0.97 & 0.29 & 1.62 & 0.000124 \\
\hline & $8.01 \pm 0.93^{b}$ & $6.90 \pm 0.75^{b}$ & $0.61 \pm 0.11^{b}$ & $4.10 \pm 0.50^{b}$ & $0.80 \pm 0.09^{b}$ & $0.08 \pm 0.01^{b}$ & $0.51 \pm 0.08^{b}$ & $0.00014 \pm 0.00005^{\mathrm{a}}$ \\
\hline MINIMUM & 7.05 & 6.05 & 0.49 & 3.46 & 0.69 & 0.06 & 0.41 & 0.0001 \\
\hline MAXIMUM & 8.93 & 7.87 & 0.71 & 4.69 & 0.90 & 0.09 & 0.61 & 0.000211 \\
\hline MEDIAN & 8.02 & 6.84 & 0.62 & 4.13 & 0.80 & 0.09 & 0.51 & 0.000137 \\
\hline MINIMUM & 7.42 & 6.01 & 0.67 & 3.23 & 0.35 & 0.16 & 0.69 & $0 . \overline{00025}$ \\
\hline MAXIMUM & 10.56 & 6.90 & 0.90 & 4.15 & 0.45 & 0.21 & 0.91 & 0.00075 \\
\hline MEDIAN & 9.01 & 6.45 & 0.79 & 3.76 & 0.40 & 0.20 & 0.80 & 0.0006 \\
\hline 4. Violet Cables & $11.10 \pm 1.77^{c}$ & $8.23 \pm 0.98^{a}$ & $0.93 \pm 0.11^{\mathrm{a}}$ & $3.82 \pm 0.37^{b}$ & $0.52 \pm 0.05^{d}$ & $0.23 \pm 0.04^{\mathrm{d}}$ & ND & $0.00051 \pm 0.00012^{b}$ \\
\hline MINIMUM & 9.15 & 7.01 & 0.80 & 3.37 & 0.46 & 0.19 & ND & $0 . \overline{00034}$ \\
\hline MAXIMUM & 13.05 & 9.42 & 1.06 & 4.26 & 0.58 & 0.28 & ND & 0.000601 \\
\hline MEDIAN & 11.10 & 8.24 & 0.94 & 3.83 & 0.52 & 0.23 & ND & 0.000551 \\
\hline BAF & 0.033 & 0.105 & 0.121 & 0.128 & 0.039 & 0.140 & ND & 0.039 \\
\hline 5. Chupetinho & $12.01 \pm 1.47^{\mathrm{a}}$ & $12.01 \pm 1.58^{\mathrm{a}}$ & $0.50 \pm 0.09^{\mathrm{a}}$ & $\begin{array}{l}\text { C. chinense } \\
7.69 \pm 1.02^{a}\end{array}$ & $0.30 \pm 0.06^{\mathrm{a}}$ & $0.17 \pm 0.02^{\mathrm{a}}$ & $0.59 \pm 0.09^{\mathrm{a}}$ & $0.00081 \pm 0.00011^{a}$ \\
\hline MINIMUM & 9.96 & 10.09 & 0.39 & 6.49 & 0.22 & 0.15 & 0.48 & 0.000709 \\
\hline $\begin{array}{l}\text { 6. Scotch Bonnet } \\
\text { Yellow }\end{array}$ & $12.60 \pm 1.83^{a}$ & $9.32 \pm 1.22^{b}$ & $1.08 \pm 0.13^{b}$ & $6.13 \pm 0.65^{b}$ & $0.42 \pm 0.06^{b}$ & $0.03 \pm 0.01^{b}$ & $0.21 \pm 0.04^{b}$ & $0.00245 \pm 0.00071^{b}$ \\
\hline MINIMUM & 10.53 & 8.05 & 0.91 & 5.31 & 0.35 & 0.02 & 0.16 & 0.00145 \\
\hline MAXIMUM & 14.53 & 10.99 & 1.19 & 6.89 & 0.49 & 0.04 & 0.25 & 0.003049 \\
\hline MEDIAN & 12.67 & 9.13 & 1.11 & 6.15 & 0.42 & 0.03 & 0.21 & 0.002649 \\
\hline 7. Bhut Jolokia Red & $11.30 \pm 1.58^{a}$ & $9.41 \pm 1.17^{b}$ & $1.00 \pm 0.16^{b}$ & $5.33 \pm 0.65^{c}$ & $0.83 \pm 0.09^{c}$ & $0.03 \pm 0.01^{b}$ & $0.83 \pm 0.11^{c}$ & $0.00014 \pm 0.00002^{c}$ \\
\hline MINIMUM & 10.05 & 8.02 & 0.85 & 4.39 & 0.72 & 0.01 & 0.72 & 0.000114 \\
\hline MAXIMUM & 13.50 & 10.81 & 1.21 & 5.90 & 0.94 & 0.04 & 0.98 & 0.000175 \\
\hline \multirow{2}{*}{ 8. Bhut Jolokia } & 10.83 & 9.41 & 0.97 & 5.51 & 0.83 & 0.03 & 0.82 & 0.000145 \\
\hline & $6.70 \pm 1.17^{b}$ & $5.95 \pm 0.63^{c}$ & $1.10 \pm 0.12^{b}$ & $3.73 \pm 0.43^{\mathrm{d}}$ & $0.90 \pm 0.10^{c}$ & $0.43 \pm 0.0529^{c}$ & $2.23 \pm 0.26^{\mathrm{d}}$ & $0.00065 \pm 0.00008^{d}$ \\
\hline MINIMUM & 5.63 & 5.19 & 1.00 & 3.17 & 0.79 & 0.382 & 2.00 & 0.00055 \\
\hline MAXIMUM & 7.74 & 6.70 & 1.27 & 4.21 & 1.02 & 0.506 & 2.54 & 0.00075 \\
\hline MEDIAN & 6.72 & 5.95 & 1.07 & 3.77 & 0.90 & 0.4255 & 2.19 & 0.000651 \\
\hline
\end{tabular}

Different lowercase letters indicate a significant difference between the treatments. ND—not detected. 
$\mathrm{Mn}, \mathrm{Zn}$ and $\mathrm{Cu}$ play an important role in enzymatic reactions as well as in cell growth, regulating tissue development, and playing a role in the body's immunity. $\mathrm{Zn}$ is the only metal that occurs in all classes of enzymes [77]. Cu is the third most common trace element in the body and is an important nutrient in food [78]. Mn is an essential element for humans, but high levels of Mn have been found to cross the placenta during pregnancy, which can affect fetal development [79]. The $\mathrm{Cr}$ content in the monitored pepper varieties was recorded in the range from 0.11 to $0.23 \mathrm{mg} / \mathrm{kg}$ FW. In the case of this monitored metal from eight varieties of the monitored pepper in three varieties (Sigaretta di Bergamo, Candlelight, Bhut Jolokia White) the limit value $(0.2 \mathrm{mg} / \mathrm{kg})$ was exceeded, which is stated in Decree no. 2/1994 Coll. Decree of the Ministry of Health of the Slovak Republic, and in one variety (Scotch Bonet Yellow) the value of $\mathrm{Cr}$ was set at the level of the limit value. According to other authors, $\mathrm{Cr}$ content in Capsicum varieties ranged from 0.03 to $1 \mathrm{mg} / \mathrm{kg}$. Due to industrial processes in the environment, large amounts of $\mathrm{Cr}$ compounds can be present, which can have adverse biological and ecological effects. Higher $\mathrm{Cr}$ content in plants degrades pigment, reduces carotene and chlorophyll content, changes the membrane structure in plants and induces oxidative stress [80,81]. $\mathrm{Cr}$ is presented in the environment mainly in two valence states $\left(\mathrm{VI}^{+}, \mathrm{III}^{+}\right)$. Hexavalent $\mathrm{Cr}$ is more dangerous than trivalent $\mathrm{Cr}$, as it can have toxic effects on humans, animals and plants. Intoxication by this metal can may occur by the consummation of contaminated drinking water, as well as the inhalation of $\mathrm{Cr}$ compounds. Genotoxic effects of $\mathrm{Cr}$ lead to DNA damage, oxidative stress, and other damage. [82,83]. The determined values of $\mathrm{Cu}$ content ranged from 0.70 to $1.75 \mathrm{mg} / \mathrm{kg} \mathrm{FW}$ and the values of Ni content were determined from 0.07 to $0.23 \mathrm{mg} / \mathrm{kg}$ FW. We can state that neither in the case of $\mathrm{Cu}$ nor in the case of Ni were the limit values exceeded in the monitored pepper varieties. Assuming that a $70 \mathrm{~kg}$ adult consumes $1 \mathrm{~g}$ of chili pepper with the highest $\mathrm{Cu}$ content $(1.75 \mathrm{mg} / \mathrm{kg})$ per day, the daily intake of $\mathrm{Cu}$ from chili peppers is $0.00175 \mathrm{mg}$, which is below the PTMI $(35 \mathrm{mg} / 70 \mathrm{~kg})$. Other authors reported higher content of $\mathrm{Cu}$ and $\mathrm{Ni}$ content in Capsicum varieties $(8.8-101 \mathrm{mg} / \mathrm{kg}$ DM 1.04-3.47 mg/kg DM, respectively) [43]. In general, $\mathrm{Cu}$ has low mobility in plants compared to other elements. Toxicity and excess of dietary $\mathrm{Cu}$ is also affected by the chemical form as well as by the interaction with other minerals ingested in the diet. The toxicity of Ni has become a subject of interest due to its increased industrial use. Ni is a micronutrient for some higher plants, its low concentration improves plant growth, but at high concentrations it is toxic to plants [84].

Cultivated crops are the main source of $\mathrm{Cd}$ and $\mathrm{Pb}$ to the human body. $\mathrm{Cd}$ is one of the metals that can significantly degrade the quantity and quality of crops grown, and often exceeds limit values in crops, as it is a significant anthropogenic pollutant [85]. The values of $\mathrm{Cd}$ content determined in the monitored varieties of Capsicum ranged from 0.010 to $0.082 \mathrm{mg} / \mathrm{kg}$ FW. We can state that in the three monitored varieties, the limit value was exceeded according to Decree no. 2/1994 Coll. Decree of the Ministry of Health of the Slovak Republic and values according to the Commission Regulation (EC) $(1881 / 2006)$. The highest exceedance of the limit value was recorded in the variety Bhut Jolokia White (1.64-fold), followed by the variety Sigaretta di Bergamo (1.30-fold) and a 1.1-fold exceedance of the limit value was recorded in the variety Candlelight. Assuming that a $70 \mathrm{~kg}$ adult consumes $30 \mathrm{~g}$ of chili pepper with highest Cd content $(0.08 \mathrm{mg} / \mathrm{kg})$ per month, the monthly intake of $\mathrm{Cd}$ from chili peppers is $0.0024 \mathrm{mg}$, which is below the PTMI $(1.75 \mathrm{mg} / 70 \mathrm{~kg})$. Other authors reported slightly lower values of Cd content in Capsicum varieties, in the range from 0.013 to $0.041 \mathrm{mg} / \mathrm{kg} \mathrm{FW}$, and from 0.018 to $0.088 \mathrm{mg} / \mathrm{kg}$ FW $[86,87]$.

According to the International Agency for Research on Cancer (IARC), Cd is a Group 1 carcinogen for humans and is associated with the incidence of lung cancer [88]. Heavy metals have the ability to replace important elements in human body, e.g., $\mathrm{Cd}$ has an atomic structure very similar to that of $\mathrm{Zn}$, and fits almost perfectly into the $\mathrm{Zn}$ binding sites of important enzymes such as RNA transferase, carboxypeptidase and alcohol dehydrogenase [89]. Cd is a very toxic element, and the contamination of the food chain with soil Cd 
poses a threat to human health. Cd in plants inhibits root growth and seed germination. Many studies have shown that the genotoxicity of $\mathrm{Cd}$ is directly related to its effect on DNA structure and function [90].

When evaluating the $\mathrm{Pb}$ content in the monitored pepper varieties, we recorded the values in the interval from ND to $0.42 \mathrm{mg} / \mathrm{kg}$ FW and we can state that in five varieties the limit value was exceeded $(0.10 \mathrm{mg} / \mathrm{kg})$, which is stated in the Commission Regulation (EC) $(1881 / 2006)$ and in one variety the value of $\mathrm{Pb}$ content was at the level of the limit value. The highest value of $\mathrm{Pb}$ content was recorded in the variety Bhut Jolokia White, where this elevation was 4.2 times. Assuming that a $70 \mathrm{~kg}$ adult consumes $30 \mathrm{~g}$ of chili pepper with the highest $\mathrm{Pb}$ content $(0.42 \mathrm{mg} / \mathrm{kg})$ per month, the monthly intake of $\mathrm{Pb}$ from chili peppers is $0.0126 \mathrm{mg}$, which is below the PTMI $(1.75 \mathrm{mg} / 70 \mathrm{~kg})$. Compared to our results, other authors reported lower values of $\mathrm{Pb}$ content $(0.007-0.023 \mathrm{mg} / \mathrm{kg})$ in their monitored chili pepper varieties [54]. The content of $\mathrm{Hg}$ in neither variety (CapsicumC. annuum and Capsicum C. chinense) exceeded the established limit value. Assuming that a $70 \mathrm{~kg}$ adult consumes $7 \mathrm{~g}$ of chili pepper with the highest $\mathrm{Hg}$ content $(0.00045 \mathrm{mg} / \mathrm{kg})$ per week, the weekly intake of $\mathrm{Hg}$ from chili peppers is $0.00000315 \mathrm{mg}$, which is below the PTWI $(0.28 \mathrm{mg} / 70 \mathrm{~kg})$. The bioaccumulation factor $(\mathrm{BAF})$ in pepper fruits showed low values (Table 5), and do not reflect the intensity of soil contamination by the determined heavy metals and indicate that the studied species of the genus Capsicum did not accumulate determined heavy metals. The processes of absorption, accumulation and transfer of heavy metals into plants are controlled by the bioavailability of metals in soils [91]. The accumulation of heavy metals in plants can lead to potential toxic effects. When plants die, the tissues break down, the heavy metals absorbed into the plants are redistributed and the soil can be enriched with these metals. Soil to plant transfer is one of the main mechanisms of human exposure to metals through food chain [92].

Therefore, it is very important to link soil properties with the phytotoxicity of monitored heavy metals in soil-crop systems, as this is one of the key steps in assessing and improving the risk of heavy metals in soil [93]. In addition to soil, the plant phytotoxicity is also affected by the plant itself, the species, the varieties, the state of development, the metabolic requirements of the plants as well as the possible abiotic stresses that may occur [94].

\subsection{Statistical Analysis}

\subsubsection{Analysis of Variance}

As shown in Figure 2, statistically significant differences were found for the $\mathrm{Cd}, \mathrm{Ni}$, and $\mathrm{Pb}$ content in the studied Capsicum annum cultivars. For Mn content, statistically significant differences were found between SDB and Cayenne, SDB and Candlelight, SDB and Violet, and between Violet and Cayenne and Violet and Candlelight. For Zn content, significant differences were found between SDB and Cayenne, SDB and Candlelight, between Violet and Cayenne and Violet and Candlelight. For $\mathrm{Cr}$ content, significant differences were found between SDB and Cayenne, SDB and Candlelight, between Violet and Cayenne, Violet and Candlelight, and between Cayenne and Candlelight. For $\mathrm{Cu}$ content, significant differences were found between SDB and Cayenne, Candlelight and Violet Cables. For HG content, significant differences were found between SDB and Candlelight and Violet, and between Cayenne and Candlelight and Violet Cables.

As shown in Figure 3, statistically significant differences were found for the $\mathrm{Cu}, \mathrm{Pb}$, and $\mathrm{Hg}$ content in the studied Capsicum chinense cultivars. For Mn content, significant differences were found between Bhut Jolokia white and other cultivars. For Zn content, significant differences were found between Chupetinho and Scotch Bonet Yellow, BJR and BJW, between BJW and BJR, CH, SBY. For Cr content, significant differences were found between Chupetinho and other cultivars. For Ni content, significant differences were found between Chupetinho and other cultivars, and between Scotch Bonet Yellow and other cultivars. For Cd content, significant differences were found between Chupetinho and other cultivars, and between BJW and other cultivars. 

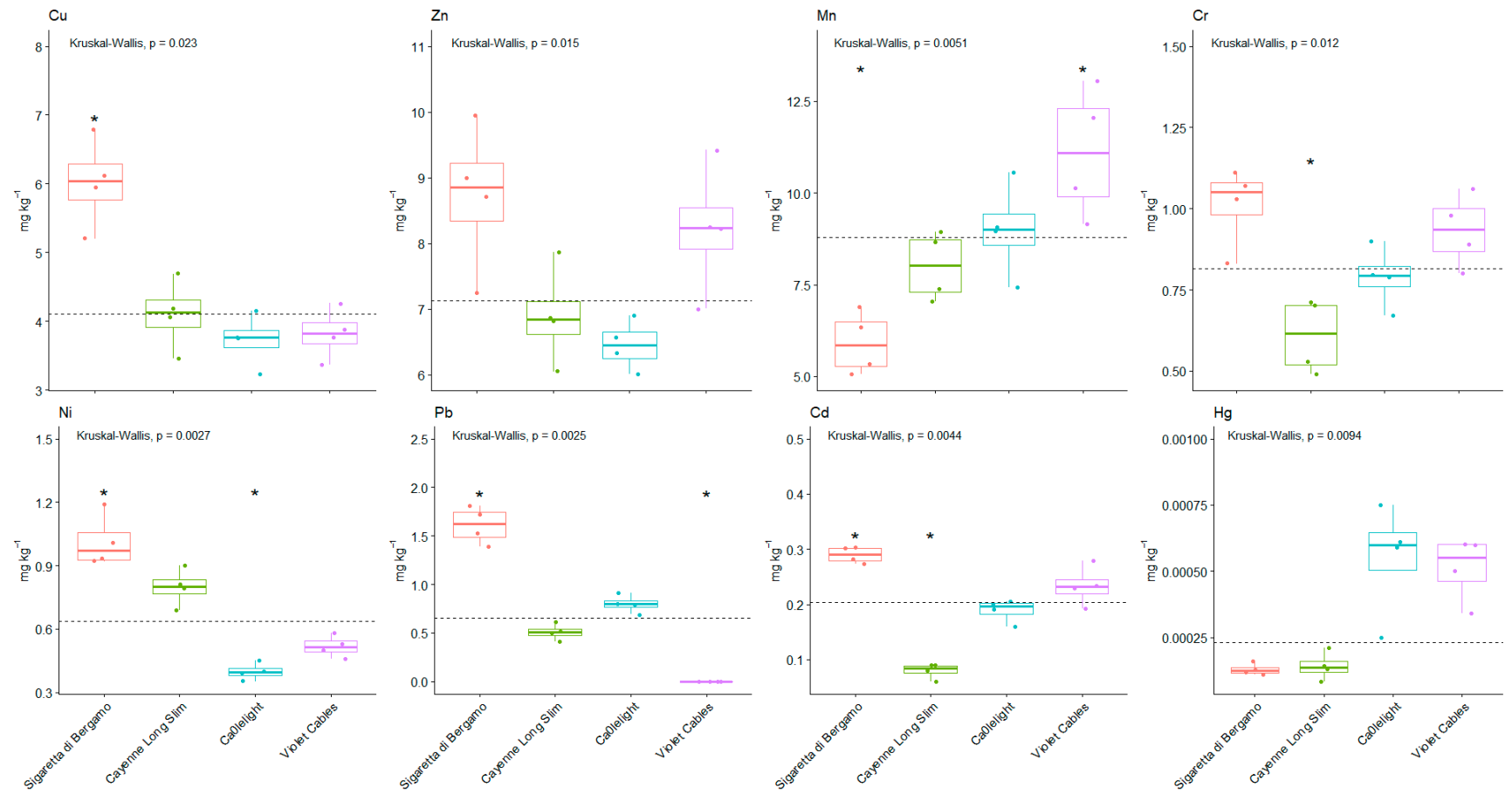

Figure 2. Differences in content of heavy metals in monitored varieties of C. annuum. $\left.{ }^{*}\right)$ indicates a significantly higher or lower values than the median.
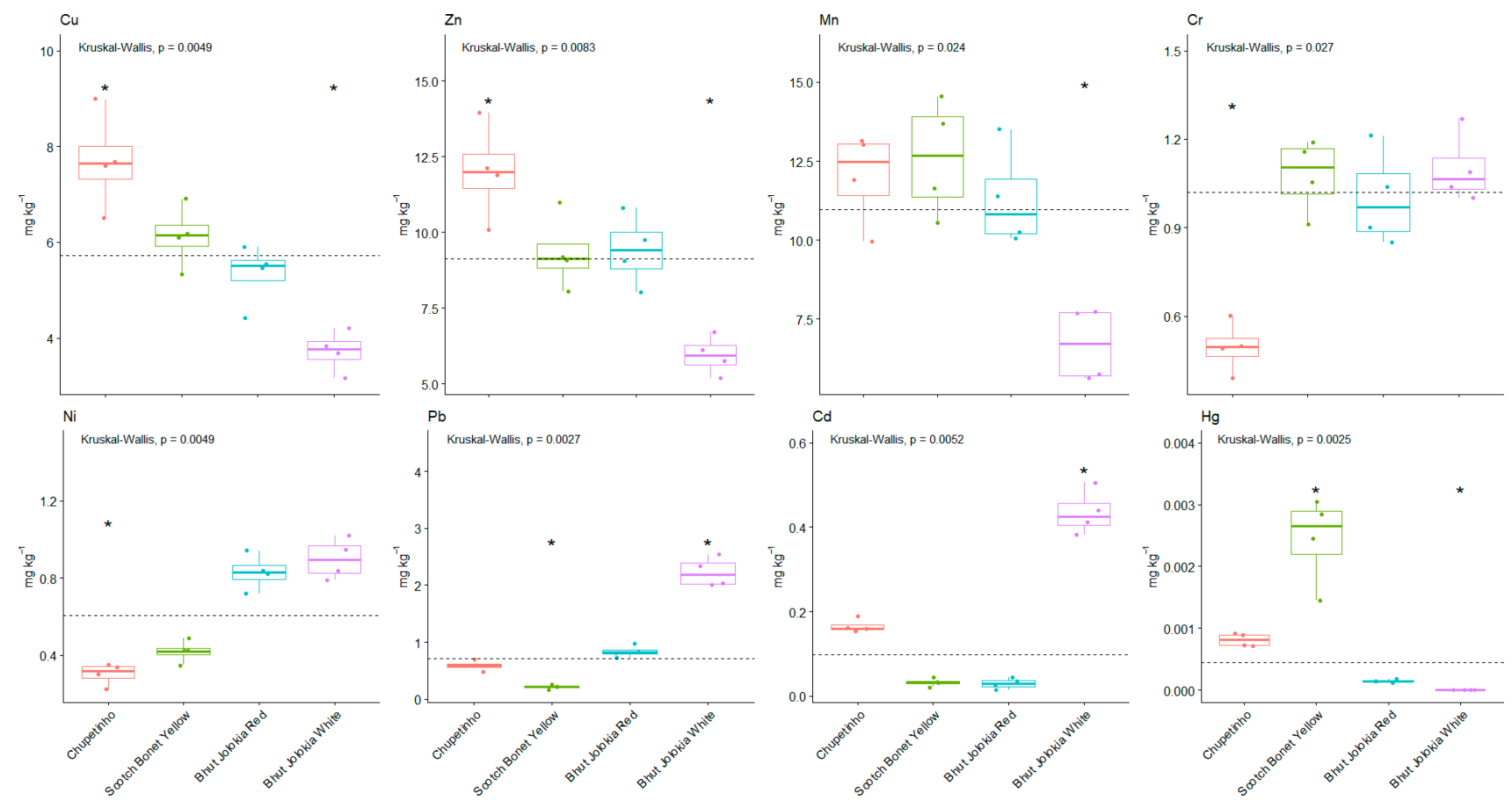

Figure 3. Differences in content of heavy metals in monitored varieties of C. chinense. $\left(^{*}\right)$ indicates a significantly higher or lower values than the median. 


\subsubsection{The Relationships between the Tested Parameters}

In order to examine the mutual relations among the analyzed parameters (total contents of heavy metals), the linear regressions were obtained. The results are shown in Figure 4 .

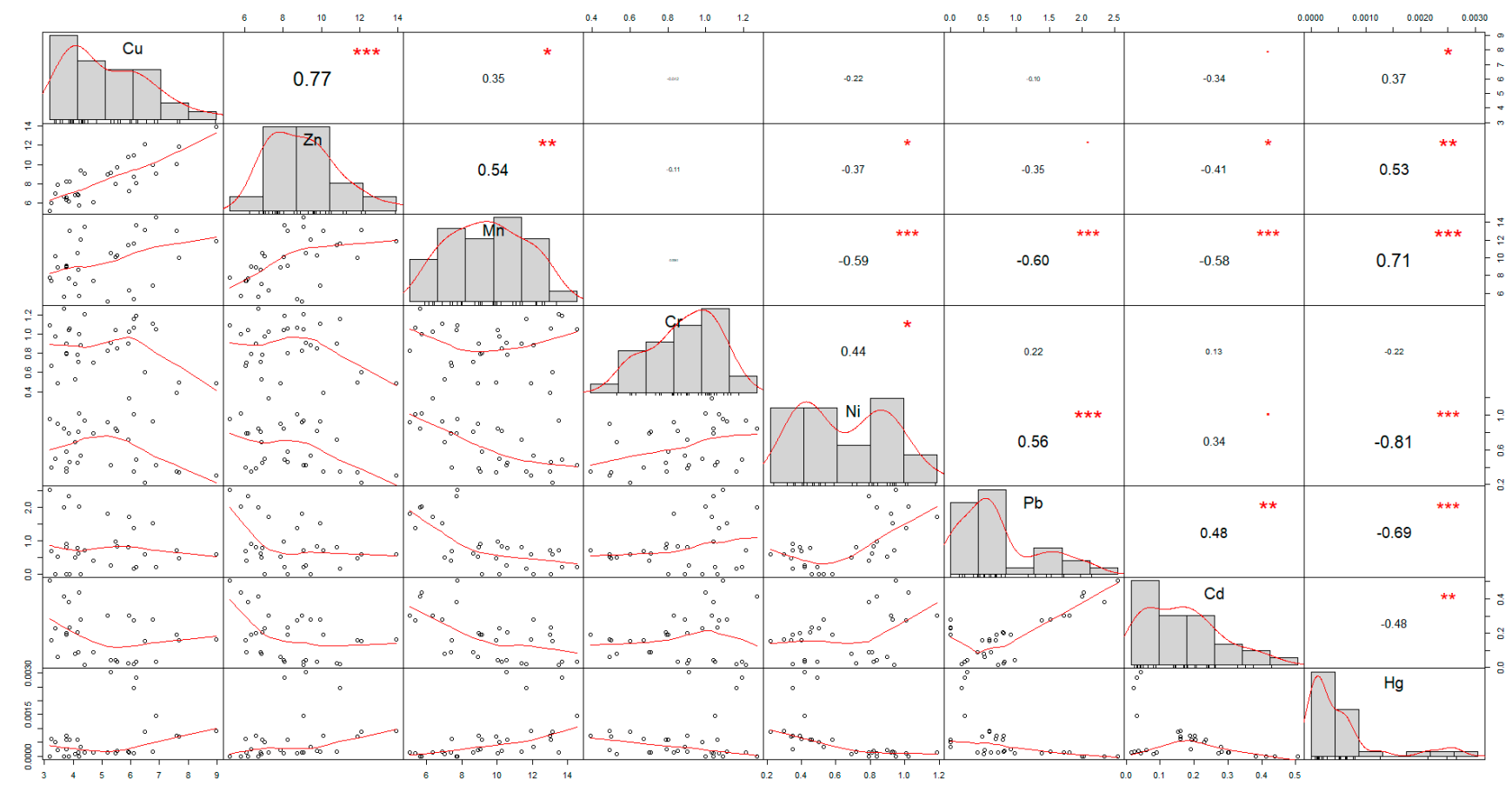

Figure 4. The relationships between the tested parameters. $\left({ }^{*}\right)$-weak correlation, $\left({ }^{* *}\right)$-moderate correlation, $(* * *)$-strong correlation.

The statistical evaluation of the results confirmed a strong correlation between $\mathrm{Cu}$ and $\mathrm{Zn}$ content $(\mathrm{r}=0.77)$, Ni and $\mathrm{Pb}$ content $(\mathrm{r}=0.56)$, and $\mathrm{Mn}$ and $\mathrm{Hg}$ content $(\mathrm{r}=0.71)$, and a strong negative correlation between $\mathrm{Mn}$ and $\mathrm{Ni}$ content $(\mathrm{r}=-0.59), \mathrm{Mn}$ and $\mathrm{Pb}$ content $(\mathrm{r}=-0.60)$, Mn and $\mathrm{Cd}$ content $(\mathrm{r}=-0.58), \mathrm{Ni}$ and $\mathrm{Hg}$ content $(\mathrm{r}=-0.81)$, and $\mathrm{Pb}$ and $\mathrm{Hg}$ content $(-0.69)$.

\subsubsection{Principal Component Analysis}

To find hidden patterns between the tested parameters, the Spearman PCA was performed. The results of the Bartlett's test of sphericity indicate that the data were likely factorable (Chi-square (observed $=156.039)$, Chi-square $($ critical $=49.801), p \leq 0.0001$ ). The principal component analysis revealed that $67.48 \%$ of the total variability embodied in eight parameters could be effectively condensed into and explained by the first two principal components, with eigenvalues of 4.04 and 1.36, respectively. The remaining principal components had eigen values below 1 ; therefore, they were not suitable for PCA analysis. The F1, accounting for $50.44 \%$ of inertia, was represented by $\mathrm{Hg}, \mathrm{Pb}, \mathrm{Ni}, \mathrm{Mn}$ and Zn contents. F2 explained $17.04 \%$ of the inertia represented mostly by $\mathrm{Cu}$ content. The observations are represented by their projections, and the variables are represented by their correlations in Figure 4. As can be seen in Figure 5, cultivars Chupetinho and Scotch Bonet Yellow are clearly characterized by $\mathrm{Mn}$ and $\mathrm{Hg}$ contents, while Sigaretta di Bergamo is characterized by $\mathrm{Ni}$ and $\mathrm{Pb}$ contents. The results of the PCA analysis also show that the Cayenne Long Slim, Candlelight and Violet Cables cultivars are similar. The cultivar Bhut Jolokia White is characterized by a high Cd content. 


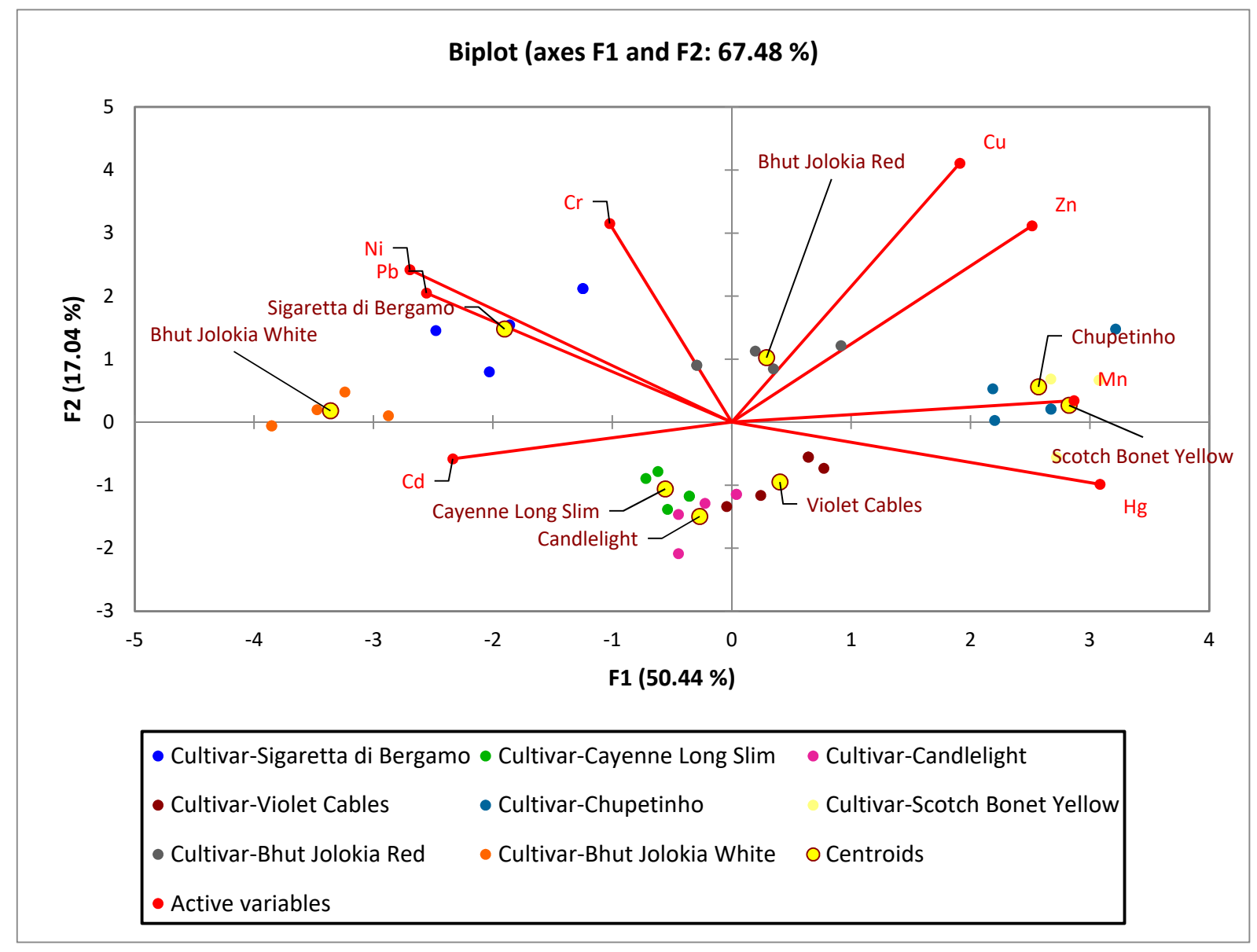

Figure 5. Plot of the first two PC loadings.

\section{Conclusions}

In southern Slovakia, the interest in growing chili peppers has been increasing recently, due to their benefits. Monitoring soil hygiene is very important, as there is a transport, transformation, or accumulation of potentially hazardous substances in the soil, which can then pass into the cultivated above-ground matter and thus seriously endanger the health of the consumer.

Our achieved results suggest that based on the contamination factor and ecological risk factor, we can characterize the soil as highly contaminated with $\mathrm{Cd}\left(\mathrm{C}_{\mathrm{f}}^{\mathrm{i}}=16.4,=492\right)$ and weakly contaminated with other heavy metals ( $\mathrm{Mn}, \mathrm{Zn}, \mathrm{Cr}, \mathrm{Cu}, \mathrm{Ni}, \mathrm{Pb}$, and $\mathrm{Hg}$ ). The limit values of bioavailable forms of $\mathrm{Cd}$ and $\mathrm{Pb}$ in soil, set by Act no. 220/2004 (valid in the Slovak Republic), were exceeded. The low bioaccumulation factor (BAF) in chili pepper fruits did not reflect the intensity of soil contamination by the determined heavy metals and indicate that the studied species of the genus Capsicum do not accumulate monitored heavy metals $(\mathrm{Mn}, \mathrm{Zn}, \mathrm{Cr}, \mathrm{Cu}, \mathrm{Ni}, \mathrm{Cd}, \mathrm{Pb}, \mathrm{Hg}$ ).

We can conclude that the monitored varieties of chili peppers in terms of content and the accumulation of heavy metals, also being based on health-based guidance values (PMTDI, PTMI, PTWI), do not pose a health risk to the consumer. Variety is one of the main factors that can affect the accumulation of heavy metals. The results show that the individual varieties of selected chili peppers did not equally accumulate the monitored heavy metals.

$\mathrm{Pb}$ accumulated most in Sigaretta di Bergamo (C. annuum) and the least in Scotch Bonnet Yellow (C. chinense). Cd accumulated the most in Bhut Jolokia White (C. chinense) and the least in Bhut Jolokia Red and Scotch Bonnet Yellow (C. chinense). The results of the PCA analysis show that cultivars Chupetinho and Scotch Bonet Yellow are characterized 
by $\mathrm{Mn}$ and $\mathrm{Hg}$ contents, while Sigaretta di Bergamo is characterized by $\mathrm{Ni}$ and $\mathrm{Pb}$ contents. The cultivar Bhut Jolokia White is characterized by a high Cd content. The results obtained can be a challenge for both the agricultural and breeding sector to grow and breed the most suitable varieties in terms of the accumulation of heavy metals and thus prevent their entry into the food chain.

Author Contributions: Conceptualization, J.L.; Methodology, L'.H.; Software, M.Š.; Formal Analysis, O.G.; Investigation, J.B.; Writing-Original Draft Preparation, J.L.; Writing-Review and Editing, N.Č.; Visualization, M.Š.; Supervision, J.M. and A.V.; Project Administration, J.M.; Funding Acquisition, J.L. and A.V. All authors have read and agreed to the published version of the manuscript.

Funding: This research was funded by scientific grant VEGA 1/0114/18.

Institutional Review Board Statement: Not applicable.

Informed Consent Statement: Not applicable.

Acknowledgments: This work was supported by scientific grant VEGA 1/0113/21.

Conflicts of Interest: The authors declare no conflict of interest.

\section{References}

1. Rai, K.P.; Sang, L.S.; Zhang, M.; Tsang, F.Y.; Kim, K. Heavy metals in food crops: Health risks, fate, mechanisms, and management. Environ. Int. 2019, 125, 365-385. [CrossRef] [PubMed]

2. Perrino, E.V.; Brunetti, G.; Farrag, K. Plant communities of multi-metal contaminated soils: A case study in National Park of Alta Murgia (Apulia Region-Southern Italy). Int. J. Phytoremediat. 2014, 16, 871-888. [CrossRef]

3. Douay, F.; Pelfrêne, A.; Planque, J.; Fourrier, H.; Richard, A.; Roussel, H.; Girondelot, B. Assessment of potential health risk for in habitants living near a former lead smelter. Part 1: Metal concentrations in soils, agricultural crops, and home grown vegetables. Environ. Monit. Assess. 2013, 185, 3665-3680. [CrossRef] [PubMed]

4. Wang, Y.; Su, Y.; Lu, S. Cd accumulation and transfer in pepper (Capsicum annuum L.) grown in typical soils of China: Pot experiments. Environ. Sci. Pollut. Res. 2019, 26, 36558-36567. [CrossRef]

5. Paltseva, A.; Cheng, Z.; Deeb, M.; Groffman, P.M.; Shaw, R.K.; Maddaloni, M. Accumulation of arsenic and lead in garden-grown vegetables: Factors and mitigation strategies. Sci. Total Environ. 2018, 640, 273-283. [CrossRef] [PubMed]

6. Mwilola, P.N.; Mukumbuta, I.; Shitumbanuma, V.; Chishala, B.H.; Uchida, Y.; Nakata, H.; Nakayama, S.; Ishizuka, N. Lead, zinc and cadmium accumulation, and associated health risks, in maize grown near the Kabwe Mine in Zambia in response to organic and inorganic soil amendments. Int. J. Environ. Res. Public Health 2020, 17, 9038. [CrossRef]

7. United States Environmental Protection Agency (EPA). Peer Review Workshop on Mercury Issues; Summary Report; Environmental Criteria and Assessment Office: Cincinnati, OH, USA, 1987.

8. Agency for Toxic Substances and Disease Registry (ATSDR). Interaction Profile for Arsenic, Cadmium, Chromium and Lead; U.S. Department of Health and Human Services, Public Health Service: Atlanta, GA, USA, 2004.

9. Kim, J.J.; Kim, Y.S.; Kumar, V. Heavy metal toxicity: An update of chelating therapeutics strategies. J. Trace Elem. Med. Biol. 2019, 54, 226-331. [CrossRef]

10. Caravanos, J.; Kevin, C.; Bret, E.; Landrigan, P.J.; Richard, F. The burden of disease from pediatric lead exposure at hazardous waste sites in 7 Asian countries. Environ. Res. 2013, 120, 119-125. [CrossRef]

11. Jan, A.; Azam, M.; Siddiqui, K.; Ali, A.; Choi, I.; Haq, Q. Heavy Metals and Human Health: Mechanistic Insight into Toxicity and Counter Defense System of Antioxidants. Int. J. Mol. Sci. 2015, 16, 29592-29630. [CrossRef]

12. Rahman, M.; Khan, H.; Jolly, Y.; Kabir, J.; Akter, S.; Salam, A. Assessing risk to human health for heavy metal contamination through street dust in the Southeast Asian Megacity: Dhaka, Bangladesh. Sci. Total Environ. 2019, 660, 1610-1622. [CrossRef]

13. Etchevers, A.; Bretin, P.; Lecoffre, C.; Bidondo, M.L.; Le Strat, Y.; Glorennec, P.; Le Tertre, A. Blood lead levels and risk factors in young children in France, 2008-2009. Int. J. Hyg. Environ. Health 2014, 217, 528-537. [CrossRef] [PubMed]

14. Kastury, F.; Smith, E.; Doelsch, E.; Lombi, E.; Donnelley, M.; Cmielewski, P.; Parsons, D.; Scheckel, K.; Paterson, D.; de Jonge, M.; et al. In Vitro, in Vivo, and Spectroscopic Assessment of lead exposure reduction via ingestion and inhalation pathways using phosphate and iron amendments. Environ. Sci. Technol. 2019, 53, 10329-10341. [CrossRef] [PubMed]

15. Tinggi, U.; Schoendorfer, N. Analysis of lead and cadmium in cereal products and duplicate diets of a small group of selected Brisbane children for estimation of daily metal exposure. J. Trace Elem. Med. Biol. 2018, 50, 671-675. [CrossRef] [PubMed]

16. Hassan, M.J.; Wang, F.; Ali, S.; Zhang, G. Toxic effects of cadmium on rice as affected by nitrogen fertilizer form. Plant. Soil 2005, 277, 359-365. [CrossRef]

17. Chibuike, G.U.; Obiora, S.C. Heavy Metal Polluted Soils: Effect on Plants and Bioremediation Methods. Appl. Environ. Soil Sci. 2014, 243-254. [CrossRef]

18. Moryani, H.T.; Kong, S.; Du, J.; Bao, J. Health Risk Assessment of Heavy Metals Accumulated on PM2.5 Fractioned Road Dust from Two Cities of Pakistan. Int. J. Environ. Res. Public Health 2020, 17, 7124. [CrossRef] 
19. Nawrot, T.S.; Martens, D.S.; Hara, A.; Plusquin, M.; Vangronsveld, J.; Roels, H.A.; Staessen, J.A. Association of total cancer and lung cancer with environmental exposure to cadmium: The meta-analytical evidence. Cancer Causes Control 2015, 26, 1281-1288. [CrossRef]

20. Satarug, S.; Vesey, D.A.; Gobe, G.C. Health risk assessment of dietary cadmium intake: Do current guidelines indicate how much is safe? Environ. Health Perspect. 2017, 125, 284-288. [CrossRef] [PubMed]

21. Joseph, P. Mechanisms of cadmium carcinogenesis. Toxicol. Appl. Pharmacol. 2009, 238, 272-279. [CrossRef]

22. Desai, V.; Kaler, S.G. Role of copper in human neurological disorders. Am. J. Clin. Nutr. 2008, 88, 855S-858S. [CrossRef]

23. Foresta, C.; Garolla, A.; Cosci, I.; Menegazzo, M.; Ferigo, M.; Gandin, V.; De Toni, L. Role of zinc trafficking in male fertility: From germ to sperm. Hum. Reprod. 2014, 29, 1134-1145. [CrossRef]

24. Rawat, N.; Tiwari, V.K.; Singh, N.; Randhawa, G.S.; Singh, K.; Chhuneja, P.; Dhaliwal, H.S. Evaluation and utilization of Aegilops and wild Triticum species for enhancing iron and zinc content in wheat. Res. Crop. Evol. 2009, 56, 53-64. [CrossRef]

25. Perrino, E.V.; Wagensommer, R.P. Crop Wild Relatives (CWR) Priority in Italy: Distribution, Ecology, In Situ and Ex Situ Conservation and Expected Actions. Sustainability 2021, 13, 1682. [CrossRef]

26. Agnew, U.M.; Slesinger, T.L. Zinc Toxicity. In StatPearls; StatPearls Publishing: Treasure Island, FL, USA, 2021.

27. Plum, L.M.; Rink, L.; Haase, H. The essential toxin: Impact of zinc on human health. Int. J. Environ. Res. Public Health 2010, 7, 1342-1365. [CrossRef] [PubMed]

28. Ramírez, A.R.; Azcona-Cruz, M.I. Toxic effects of manganese. Rev. Espec. Médico Quirúrgicas 2018, 22, 71-75.

29. Oliveira, H. Chromium as an Environmental Pollutant: Insights on Induced Plant Toxicity. J. Bot. 2012, 2012, 375843. [CrossRef]

30. Shrivastava, R.; Upreti, R.K.; Seth, P.K.; Chaturvedi, U.C. Effects of chromium on the immune system. FEMS Microbiol. Immunol. 2002, 34, 1-7. [CrossRef] [PubMed]

31. Bagchi, D.; Bagchi, M.; Stohs, S.J. Chromium (VI)-induced oxidative stress, apoptotic cell death and modulation of p53 tumor suppressor gene. Mol. Cell. Biochem. 2001, 222, 149-158. [CrossRef]

32. IARC. Chromium, nickel and welding. In IARC Monographs on the Evaluation of Carcinogenic Risks to Humans; IARC: Lyon, France, 1990; Volume 49, pp. 1-687.

33. Stoj, C.; Kosman, D.J. Cuprous oxidase activity of yeast Fet3p and human ceruloplasmin: Implication for function. FEBS Lett. 2003, 554, 422-426. [CrossRef]

34. Itoh, S.; Kondo, T.; Komatsu, M.; Ohshiro, Y.; Li, C.; Kanehisa, N.; Kai, Y.; Fukuzumi, S. Functional Model of Dopamine.beta.Hydroxylase. Quantitative Ligand Hydroxylation at the Benzylic Position of a Copper Complex by Dioxygen. J. Am. Chem. Soc. 1995, 117, 4714-4715. [CrossRef]

35. Barber, R.G.; Grenier, Z.A.; Burkhead, J.L. Copper Toxicity Is Not Just Oxidative Damage: Zinc Systems and Insight from Wilson Disease. Biomedicines 2021, 9, 316. [CrossRef] [PubMed]

36. Myśliwa-Kurdziel, B.; Prasad, M.N.V.; Strzałtka, K. Photosynthesis in heavy metal stressed plants. In Heavy Metal Stress in Plants; Springer: Berlin/Heidelberg, Germany, 2004; pp. 146-181.

37. Buxton, S.; Garman, E.; Heim, K.E.; Lyons-Darden, T.; Schlekat, C.E.; Taylor, M.D.; Oller, A.R. Concise review of nickel human health toxicology and ecotoxicology. Inorganics 2019, 7, 89. [CrossRef]

38. Fernandes Azevedo, B.; Barros Furieri, L.; Peçanha, F.M.; Wiggers, G.A.; Frizera Vassallo, P.; Ronacher Simões, M.; Valentim Vassallo, D. Toxic effects of mercury on the cardiovascular and central nervous systems. J. Biomed. Biotechnol. 2012, 949048. [CrossRef]

39. Patra, M.; Bhowmik, N.; Bandopadhyay, B.; Sharma, A. Comparison of mercury, lead and arsenic with respect to genotoxic effects on plant systems and the development of genetic tolerance. Environ. Exp. Bot. 2004, 52, 199-223. [CrossRef]

40. Affum, G.A.O.; Osae, S.D.; Kwaansa-Ansah, E.E.; Miyittah, M.K. Quality assessment and potential health risk of heavy metals in leafy and non-leafy vegetables irrigated with groundwater and municipal-waste-dominated stream in the Western region, Ghana. Heliyon 2020, 6, e05829. [CrossRef] [PubMed]

41. Antonious, G.F. Distribution of seven heavy metals among hot pepper plant parts. J. Environ. Sci. Health Part B 2016, 51, 309-315. [CrossRef] [PubMed]

42. Shaha, R.K.; Rahman, S.; Asrul, A. Bioactive compounds in chilli peppers (Capsicum annuum L.) at various ripening (green, yellow and red) stages. Ann. Biol. Res. 2013, 4, 27-34.

43. Antonious, G.F.; Kochhar, T.S. Mobility of Heavy Metals from Soil into Hot Pepper Fruits: A Field Study. Bull. Environ. Contam. Toxicol. 2008, 82, 59-63. [CrossRef]

44. Aslam, R.; Ansari, M.Y.K.; Choudhary, S.; Bhat, T.M.; Jahan, N. Genotoxic effects of heavy metal cadmium on growth, biochemical, cyto-physiological parameters and detection of DNA polymorphism by RAPD in Capsicum annuum L.-An important spice crop of India. Saudi J. Biol. Sci. 2014, 21, 465-472. [CrossRef]

45. Aslam, R.; Bhat, T.M.; Choudhary, S.; Ansari, M.Y.K. An overview on genotoxicity of heavy metal in a spice crop (Capsicum annuиm L.) in respect to cyto-morphological behavior. Caryologia 2017, 70, 42-47. [CrossRef]

46. Dorne, J.L.; Kass, G.E.; Bordajandi, L.R.; Amzal, B.; Bertelsen, U.; Castoldi, A.F.; Heppner, C.; Eskola, M.; Fabiansson, S.; Ferrari, P.; et al. Human risk assessment of heavy metals: Principles and applications. Met. Ions Life Sci. 2011, 8, 27-60. [PubMed]

47. Barlow, S.M.; Boobis, A.R.; Bridges, J.; Cockburn, A.; Dekant, W.; Hepburn, P.; Bánáti, D. The role of hazard- and risk-based approaches in ensuring food safety. Trends Food Sci. Technol. 2015, 46, 176-188. [CrossRef] 
48. Relief Map of Slovakia. Available online: https://sk.wikipedia.org/wiki/S\%C3\%BAbor:Relief_Map_of_Slovakia.png (accessed on 28 May 2021).

49. Background Map of the Nitra Region, Slovakia, Ready for the Geobox Template, Calibrated at en:Template:Geobox Locator Nitra Region, Outline Map of the Nitra Region, Slovakia, Ready for the Geobox Template, Calibrated at en:Template:Geobox Locator Nitra Region. Available online: https://sk.wikipedia.org/wiki/S\%C3\%BAbor:Nitra_Region_-_physical_map.png (accessed on 28 May 2021).

50. Nikitin, B.A. Method for humus determination. AGROKHIMIIA 1999, 3, 91-93.

51. Fiala, K. Obligatory methods of soil analysis. In Partial Monitoring System-Soil; VUPOP: Bratislava, Slovakia, 1999. (In Slovak)

52. Mehlich, A. Mehlich 3 soil test extractant: A modification of the Mehlich 2 extractant. Commun. Soil Sci. Plant. Anal. 1984, 15, 1409-1416. [CrossRef]

53. Árvay, J.; Demková, L.; Hauptvogl, M.; Michalko, M.; Bajčan, D.; Stanovič, R.; Trebichalský, P. Assessment of environmental and health risks in former polymetallic ore mining and smelting area, Slovakia: Spatial distribution and accumulation of mercury in four different ecosystems. Ecotoxicol. Environ. Saf. 2015, 144, 236-244. [CrossRef]

54. Jimoh, A.; Agbaji, E.B.; Ajibola, V.O.; Funtua, M.A. Application of Pollution Load Indices, Enrichment Factors, Contamination Factor and Health Risk Assessment of Heavy Metals Pollution of Soils of Welding Workshops at Old Panteka Market, KadunaNigeria. Open J. Anal. Bioanal. Chem. 2020, 4, 11-19. [CrossRef]

55. Hakanson, L. An ecological risk index for aquatic pollution control. A sedimentological approach. Water Res. 1980, 14, 975-1001. [CrossRef]

56. Linkeš, V.; Kobza, J.; Švec, M.; Ilka, P.; Pavlenda, P.; Barančíková, G.; Matúšková, L. Soil Monitoring of Slovak Republic Present State of Monitored Soil Properties; Vyskumny Ustav Podnej Urodnosti: Bratislava, Slovakia, 1997; pp. 39-51.

57. Luo, W.; Lu, Y.; Gisey, J.P.; Wang, T.; Shi, Y.; Wang, G.; Xing, Y. Effects of land use on concentrations of metals in surface soils and ecological risk around Guanting Reservoir, China. Environ. Geochem. Health 2007, 29, 459-471. [CrossRef] [PubMed]

58. Islam, S.; Ahmed, K.; Al-Mamun, M.H.; Masunaga, S. Potential ecological risk of hazardous elements in different land-use urban soils of Bangladesh. Sci. Total Environ. 2015, 512-513, 94-102. [CrossRef]

59. Yakun, S.; Xingmin, M.; Kairong, L.; Hongbo, S. Soil characterization and differential patterns of heavy metal accumulation in woody plants grown in coal gangue wastelands in Shaanxi, China. Environ. Sci. Pollut. Res. 2016, 23, 13489-13497. [CrossRef]

60. Islam, M.S.; Ahmed, M.K.; Al-Mamun, M.H.; Hoque, M.F. Preliminary assessment of heavy metal contamination in surface sediments from a river in Bangladesh. Environ. Earth Sci. 2014, 73, 1837-1848. [CrossRef]

61. Dryžalowska, A.; Falandysz, J. Bioconcentration of mercury by mushroom Xerocomus chrysenteron from the spatially distinct locations: Levels, possible intake and safety. Ecotoxicol. Environ. Saf. 2014, 107, 97-102. [CrossRef] [PubMed]

62. Herman, J.I.; Younes, M. Background to the ADI/TDI/PTWI. Regul Toxicol Pharm. 1999, 30, 109-113. [CrossRef] [PubMed]

63. World Health Organization. Principles and Methods for the Risk Assessment of Chemicals in Food; World Health Organization: Geneva, Switzerland, 2009.

64. Mózsik, G. It remains a mystery why people living in hot climates consume spicier food. Temperature 2016, 3, 50-51. [CrossRef] [PubMed]

65. Addinsoft, XLSTAT. Analyse de Donneés et Statistique Avec MS Excel; Addinsoft: New York, NY, USA, 2014.

66. RStudio Team. RStudio: Integrated Development for R; RStudio, Inc.: Boston, MA, USA, 2005; Available online: http:/ / www.rstudio. $\mathrm{com} /$ (accessed on 1 May 2021).

67. Jaishankar, M.; Tseten, T.; Anbalagan, N.; Mathew, B.B.; Beeregowda, K.N. Toxicity, mechanism and health effects of some heavy metals. Interdiscip. Toxicol. 2014, 7, 60-72. [CrossRef]

68. Antoniadis, V.; Levizou, E.; Shaheen, S.M.; Ok, Y.S.; Sebastian, A.; Baum, C.; Prasad, M.N.V.; Wenzel, W.W.; Rinklebe, J. Trace elements in the soil-plant interface: Phytoavailability, translocation, and phytoremediation-A review. Earth Sci. Rev. 2017, 171, 621-645. [CrossRef]

69. Zhao, F.J.; Ma, Y.; Zhu, Y.G.; Tang, Z.; McGrath, S.P. Soil Contamination in China: Current Status and Mitigation Strategies. Environ. Sci. Technol. 2014, 49, 750-759. [CrossRef]

70. Zhong, X.; Chen, Z.; Li, Y.; Ding, K.; Liu, W.; Liu, Y.; Qiu, R. Factors Influencing Heavy Metal Availability and Risk Assessment of Soils at Typical Metal Mines in Eastern China. J. Hazard. Mater. 2020, 400, 123289. [CrossRef] [PubMed]

71. Khan, S.; Reid, B.J.; Li, G.; Zhu, Y.G. Application of biochar to soil reduces cancer risk via rice consumption: A case study in Miaoqian village, Longyan, China. Environ. Int. 2014, 68, 154-161. [CrossRef] [PubMed]

72. Cao, X.; Wang, X.; Tong, W.; Gurajala, H.K.; Lu, M.; Hamid, Y.; Feng, Y.; He, Z.; Yang, X. Distribution, availability and translocation of heavy metals in soil oilseed rape (Brassica napus L.) system related to soil properties. Environ. Pollut. 2019, 252, 733-741. [CrossRef] [PubMed]

73. Wei, B.; Yu, J.; Cao, Z.; Meng, M.; Yang, L.; Chen, Q. The Availability and Accumulation of Heavy Metals in Greenhouse Soils Associated with Intensive Fertilizer Application. Int. J. Environ. Res. Public Health 2020, 17, 5359. [CrossRef]

74. Zejnulahu, B.; Kucaj, E.; Abazi, U.; Harizaj, F. Evaluation of heavy metal content in Capsicum annuum in Obiliq, Kosovo. Am. J. Eng. Res. 2017, 6, 186-189.

75. Nenman, D.V.; Nanven, N.D.; Ezekiel, D.I. Trace metals accumulation in some irrigated vegetables grown around Heipang Village Plateau State. Glob. Eng. Technol. Rev. 2012, 2, 11-15.

76. World Health Organization. Trace Elements in Human Nutrition and Health; World Health Organization: Geneva, Switzerland, 1996. 
77. Broadley, M.R.; White, P.J.; Hammond, J.P.; Zelko, I.; Lux, A. Zinc in plants. New Phytol. 2007, 173, 677-702. [CrossRef] [PubMed]

78. Osredkar, J.; Sustar, N. Copper and zinc, biological role and significance of copper/zinc imbalance. J. Clinic. Toxicol. S 2011, 3.2161, 0495. [CrossRef]

79. USEPA. USEPA-Integrated Risk Information System (IRIS) on Manganese. In National Center for Environmental Assessment; Office of Research and Development: Washinton, DC, USA, 1999.

80. Panda, S.K.; Patra, H.K. Does Cr(III) produces oxidative damage in excised wheat leaves. J. Plant. Biol. 2000, 27, 105-110.

81. Panda, S.K.; Choudhury, S. Chromium stress in plants. Braz. J. Plant. Physiol. 2005, 17, 95-102. [CrossRef]

82. Mishra, S.; Bharagava, R.N. Toxic and genotoxic effects of hexavalent chromium in environment and its bioremediation strategies. J. Environ. Sci. Health Part C 2016, 34, 1-32. [CrossRef]

83. Wise, J.T.; Wang, L.; Xu, J.; Zhang, Z.; Shi, X. Oxidative stress of Cr (III) and carcinogenesis. In The Nutritional Biochemistry of Chromium (III); Elsevier: Amsterdam, The Netherlands, 2019; pp. 323-340. [CrossRef]

84. Gumi, A.M.; Sufiyanu, S. Effect of nickel on growth, pigmentation and ion homeostasis of Capsicum annum L. and Capsicum chinense L. Adv. Agric. Sci. Eng. Res. 2013, 3, 1430-1436, ISSN 2276-6723.

85. Rahman, M.F.; Ghosal, A.; Alam, M.F.; Kabir, A.H. Remediation of cadmium toxicity in field peas (Pisum sativum L.) through exogenous silicon. Ecotoxicol. Environ. Saf. 2017, 135, 165-172. [CrossRef] [PubMed]

86. Chen, L.; Cui, Z.X.; Wang, D. Variations in $\mathrm{Cd}$ and $\mathrm{Pb}$ accumulations of hot pepper (Capsicum annuum L.) cultivars for screening pollution- and nitrate-safe cultivars. Pol. J. Environ. Stud. 2020, 29, 2597-2607. [CrossRef]

87. Morikawa, C.K. Reducing Cadmium Accumulation in Fresh Pepper Fruits by Grafting. Hort. J. 2017, 86, 45-51. [CrossRef]

88. Lener, M.R.; Reszka, E.; Marciniak, W.; Lesicka, M.; Baszuk, P.; Jabłońska, E.; Lubiński, J. Blood cadmium levels as a marker for early lung cancer detection. J. Trace Elem. Med. Biol. 2021, 64, 126682. [CrossRef]

89. Wilson, L.; Toxic Metals and Human Health. The Centre for Development. 2011. Available online: http://drlwilson.com/articles/ TOXIC\%20METALS.htm (accessed on 1 May 2021).

90. Cambier, S.; Gonzalez, P.; Durrieu, G.; Bourdineaud, J.P. Cadmium-induced genotoxicity in zebrafish at environmentally relevant doses. Ecotox. Environ. Saf. 2010, 73, 312-319. [CrossRef]

91. Chen, H.; Yuan, X.; Li, T.; Hu, S.; Ji, J.; Wang, C. Characteristics of heavy metal transfer and their influencing factors in different soil-crop systems of the industrialization region, China. Ecotoxicol. Environ. Saf. 2016, 126, 193-201. [CrossRef]

92. Árvay, J.; Tomáš, J.; Hauptvogl, M.; Massányi, P.; Harangozo, L'.; Tóth, T.; Stanovič, R.; Bryndzová, Š.; Bumbalová, M. Human exposure to heavy metals and possible public health risks via consumption of wild edible mushrooms from Slovak Paradise National Park, Slovakia. J. Environ. Sci. Health Part B 2015, 50, 833-843. [CrossRef] [PubMed]

93. Xiao, W.; Yea, X.; Zhang, Q.; Chen, D.; Hu, J.; Gao, N. Evaluation of cadmium transfer from soil to leafy vegetables: Influencing factors, transfer models, and indication of soil threshold contents. Ecotoxicol. Environ. Saf. 2018, 164, 355-362. [CrossRef]

94. Reboredo, F. Zinc compartmentation in Halimione portulacoides (L.) Aellen and some effects on leaf ultrastructure. Environ. Sci. Pollut. Res. 2012, 19, 2644-2657. [CrossRef] [PubMed] 